Check for updates

Cite this: RSC Adv., 2022, 12, 5324

Received 13th December 2021 Accepted 28th January 2022

DOI: $10.1039 / \mathrm{d} 1 \mathrm{ra09027e}$

rsc.li/rsc-advances

\section{Coordination complexes constructed from pyrazole-acetamide and pyrazole-quinoxaline: effect of hydrogen bonding on the self-assembly process and antibacterial activity $\dagger$}

\author{
Karim Chkirate, ${ }^{a}$ Khalid Karrouchi, (D) *b Hind Chakchak, ${ }^{c}$ Joel T. Mague, (D) $d$ \\ Smaail Radi, (D) e N. N. Adarsh, (D) ${ }^{f}$ Weiyang Li, ${ }^{g}$ Ahmed Talbaoui, ${ }^{h}$ El Mokhtar Essassi ${ }^{a}$ \\ and Yann Garcia (D)*g
}

Two mononuclear coordination complexes of $\mathrm{N}$-(2-aminophenyl)-2-(5-methyl-1H-pyrazol-3-yl) acetamide $\left(\mathrm{L}_{1}\right)$, namely $\left[\mathrm{Cd}\left(\mathrm{L}_{1}\right)_{2} \mathrm{Cl}_{2}\right]\left(\mathrm{C}_{1}\right)$ and $\left[\mathrm{Cu}\left(\mathrm{L}_{1}\right)_{2}\left(\mathrm{C}_{2} \mathrm{H}_{5} \mathrm{OH}\right)_{2}\right]\left(\mathrm{NO}_{3}\right)_{2}\left(\mathrm{C}_{2}\right)$ and one mononuclear complex $\left[\mathrm{Fe}\left(\mathrm{L}_{2}\right)_{2}\left(\mathrm{H}_{2} \mathrm{O}\right)_{2}\right]\left(\mathrm{NO}_{3}\right)_{2} \cdot 2 \mathrm{H}_{2} \mathrm{O}\left(\mathrm{C}_{3}\right)$, obtained after in situ oxidation of $\mathrm{L}_{1}$, have been synthesized and characterized spectroscopically. As revealed by single-crystal $\mathrm{X}$-ray diffraction, each coordination sphere made of two heterocycles is completed either by two chloride anions (in $C_{1}$ ), two ethanol molecules (in $C_{2}$ ) or two water molecules (in $C_{3}$ ). The crystal packing analysis of $C_{1}, C_{2}$ and $C_{3}$, revealed $1 \mathrm{D}$ and 2D supramolecular architectures, respectively, via various hydrogen bonding interactions, which are discussed in detail. Furthermore, evaluation in vitro of the ligands and their metal complexes for their antibacterial activity against Escherichia coli (ATCC 4157), Pseudomonas aeruginosa (ATCC 27853), Staphylococcus aureus (ATCC 25923) and Streptococcus fasciens (ATCC 29212) strains of bacteria, revealed outstanding results compared to chloramphenicol, a well-known antibiotic, with a normalized

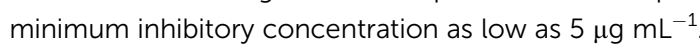

\section{Introduction}

There is growing interest in the development of new active antibacterial compounds as current clinical treatments remain insufficient to meet the challenge of the increasing emergence and spread of antimicrobial resistance. ${ }^{\mathbf{1}}$ In Europe, antibiotic

\footnotetext{
${ }^{a}$ Laboratory of Heterocyclic Organic Chemistry, Department of Chemistry, Faculty of Sciences, Mohamed V University, BP1014, Rabat, 10100, Morocco

${ }^{b}$ Laboratory of Analytical Chemistry and Bromatology, Faculty of Medicine and Pharmacy, Mohammed V University in Rabat, Morocco. E-mail: khalid.karrouchi@ um5s.net.ma

'Unités d'Appui Techniques À la Recherche Scientifique (UATRS), Centre National Pour la Recherche Scientifique et Technique (CNRST), Rabat, 10000, Morocco

${ }^{d}$ Mohammed First University, Oujda, Faculty of Sciences Oujda, LCAE, Oujda, Morocco ${ }^{e} L C A E$, Département de Chimie, Faculté des Sciences, Université Mohamed I, BP 524, 60000 Oujda, Morocco

fSchool of Chemical Sciences, Mahatma Gandhi University, Kottayam, 686560, Kerala, India

${ }^{I}$ Institute of Condensed Matter and Nanosciences, Molecular Chemistry, Materials and Catalysis (IMCN/MOST), Université catholique de Louvain, Place L. Pasteur 1, 1348 Louvain-la-Neuve, Belgium. E-mail: yann.garcia@uclouvain.be

${ }^{h}$ Laboratoire de Biologie des Pathologies Humaines, Faculté des Sciences, Université Mohammed $V$ de Rabat, Morocco

$\dagger$ Electronic supplementary information (ESI) available. CCDC 2095071-2095073 for $\mathbf{C}_{1}, \mathbf{C}_{2}$ and $\mathbf{C}_{3}$. For ESI and crystallographic data in CIF or other electronic format see DOI: 10.1039/d1ra09027e
}

resistance is responsible for approximately 33000 deaths per year. ${ }^{2}$ In the United States, more than 2.8 million people suffer from antibiotic-resistant infections, resulting in more than 35000 deaths each year. ${ }^{3}$ In 2019, the WHO identified 32 antibiotics in clinical development that address the WHO's list of priority pathogens, of which only six were classified as innovative. Furthermore, a lack of access to quality antimicrobials remains a major issue. Antibiotic shortages are affecting countries of all levels of development and especially in healthcare systems. ${ }^{4}$ Therefore, there is an urgent need to develop new antimicrobial agents.

Nitrogen-based ligands are attracting growing attention due to their interesting properties in structural and inorganic chemistry. ${ }^{5}$ Pyrazole derivatives are biologically active heterocyclic compounds. ${ }^{6-8}$ This substance class has been the topic of numerous pharmaceutical studies being used for their medicinal properties such as anti-inflammatory, ${ }^{9}$ antidiabetic, ${ }^{\mathbf{1 0}, 11}$ antiviral, ${ }^{12}$ analgesic, ${ }^{13}$ antitumor,${ }^{14}$ catecholase, ${ }^{15}$ and antimicrobial properties. ${ }^{\mathbf{1 6}}$

On other hand, nitrogen systems have attracted more attention in recent years because of their interesting properties in coordination chemistry. ${ }^{\mathbf{1 7 - 1 9}}$ However, many reports on transition metal complexes explain their efficient bioactivity against a range of bacterial and fungal species. ${ }^{20-22}$ In particular, heterocyclic metal complexes dominated medicinal chemistry 


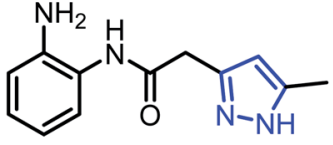

$L_{1}$<smiles>Cc1cc(-c2nc3ccccc3[nH]c2=O)n[nH]1</smiles>

$\mathrm{L}_{2}$
Fig. 1 Structures of $\mathrm{N}$-(2-aminophenyl)-2-(5-methyl-1H-pyrazol-3yl)acetamide $\left(L_{1}\right)$ and 3 - (5-methyl- $1 H$-pyrazol-3-yl)quinoxalin-2(1H)one $\left(L_{2}\right)$.

due to their wide range of properties..$^{23-25}$ Metal complexes tethered with heterocyclic moieties like imidazole, pyrazole, 1,2,4-triazoles and benzimidazole have received remarkable interest as broad spectrum antibacterial, antifungal and antiviral agents. ${ }^{26-29}$ Therefore, the antibacterial activity of many metal complexes has been demonstrated against several bacterial species both in vitro and in vivo, making it as promising antibacterial agents for use against these bacteria, pending a greater understanding of its safety upon systemic or topical administration in humans. ${ }^{30-36}$ Recently, a study investigated organometallic compounds submitted to the Community for Open Antimicrobial Drug Discovery (CO-ADD) databank, established a classification based on the nature of their metal element, activity, as well as toxicity. ${ }^{37}$ Metalcontaining compounds show actually a significantly higher success rate $(9.9 \%)$ compared to purely organic molecules $(0.87 \%)$. Out of 906 compounds, 88 show activity against at least one of the tested strains, including fungi, while showing no cytotoxicity against mammalian cell lines or hemolytic properties. Amongst the metal complexes, cadmium, copper and iron, were the most frequent elements found in active 'non-toxic' compounds and show the highest overall success rate. ${ }^{37}$

In order to search for new ligand candidates for assemblies of metal complexes, we considered the case of pyrazole acetamide ligands with $\mathrm{O}$ and $\mathrm{N}$ donor atoms. ${ }^{38-40}$ These molecules are particularly interesting as ligands for the construction of polynuclear complexes as models for bioinorganic systems. ${ }^{41,42}$ As a continuation of our research along this line ${ }^{43,44}$ we have

Table 1 Refinement parameters and crystal data for $C_{1}, C_{2}$ and $C_{3}$

\begin{tabular}{|c|c|c|c|}
\hline CCDC number & 2095071 & 2095072 & 2095073 \\
\hline Chemical formula & $\mathrm{C}_{24} \mathrm{H}_{28} \mathrm{CdCl}_{2} \mathrm{~N}_{8} \mathrm{O}_{2}$ & $\mathrm{C}_{28} \mathrm{H}_{40} \mathrm{CuN}_{8} \mathrm{O}_{4} \cdot 2\left(\mathrm{NO}_{3}\right)$ & $\begin{array}{l}\mathrm{C}_{24} \mathrm{H}_{24} \mathrm{FeN}_{8} \mathrm{O}_{4} \cdot 2\left(\mathrm{NO}_{3}\right) \\
2\left(\mathrm{H}_{2} \mathrm{O}\right)\end{array}$ \\
\hline$M_{\mathrm{r}}$ & 643.84 & 740.24 & 704.41 \\
\hline$a, b, c(\AA)$ & $\begin{array}{l}\text { 13.7075(8), } 21.2787(13) \\
9.1536(6)\end{array}$ & $\begin{array}{l}9.0258(5), 10.0091(6) \\
11.2402(6)\end{array}$ & $\begin{array}{l}8.392(3), 11.420(4) \\
15.823(6)\end{array}$ \\
\hline$\alpha, \beta, \gamma\left({ }^{\circ}\right)$ & $\beta: 95.127(1)$ & $\begin{array}{l}\text { 74.769(1), 66.668(1), } \\
80.782(1)\end{array}$ & $\begin{array}{l}78.679(4), 86.124(4) \\
80.487(4)\end{array}$ \\
\hline$V\left(\AA^{3}\right)$ & $2659.2(3)$ & $897.84(9)$ & $1465.5(9)$ \\
\hline$Z$ & 4 & 1 & 2 \\
\hline \multicolumn{4}{|l|}{ Data collection } \\
\hline Diffractometer & Bruker Smart APEX CCD & & \\
\hline Absorption correction & Multi-scan SADABS & & \\
\hline$T_{\min }, T_{\max }$ & $0.75,0.88$ & $0.82,0.93$ & $0.73,0.98$ \\
\hline $\begin{array}{l}\text { No. of measured, independent and observed }[I>2 \sigma(I)] \\
\text { reflections }\end{array}$ & $25873,7227,6853$ & $16816,4438,3338$ & $12137,6014,3364$ \\
\hline$R_{\text {int }}$ & 0.029 & 0.031 & 0.042 \\
\hline$(\sin \theta / \lambda)_{\max }\left(\AA^{-1}\right)$ & 0.698 & 0.668 & 0.629 \\
\hline \multicolumn{4}{|l|}{ Refinement } \\
\hline$R\left[F^{2}>2 \sigma\left(F^{2}\right)\right], \mathrm{w} R\left(F^{2}\right), S$ & $0.023,0.053,1.03$ & $0.045,0.129,1.03$ & $0.069,0.215,1.00$ \\
\hline No. of reflections & 7227 & 4438 & 6014 \\
\hline
\end{tabular}




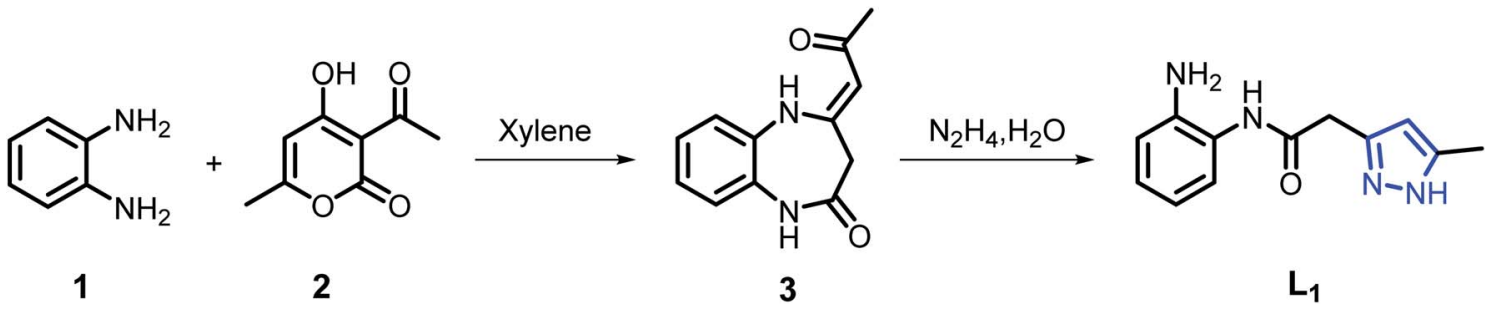

Scheme 1 Synthetic route for preparation of $L_{1}$.

successfully synthesized three new $\mathrm{Cd}(\mathrm{II}), \mathrm{Cu}(\mathrm{II})$ and $\mathrm{Fe}(\mathrm{II})$ coordination complexes derived from the ligands, namely $\mathrm{N}$-(2aminophenyl)-2-(5-methyl-1 $H$-pyrazol-3-yl)acetamide $\left(\mathbf{L}_{\mathbf{1}}\right)$ and 3(5-methyl-1H-pyrazol-3-yl)quinoxalin-2(1H)-one $\left(\mathbf{L}_{2}\right)$ (Fig. 1). The molecular structures of the complexes were confirmed by single-crystal X-ray diffraction. All ligands and metal complexes were evaluated in vitro for their antibacterial activity against Escherichia coli (ATCC 4157), Pseudomonas aeruginosa (ATCC

Table 2 Hydrogen-bond geometry $\left(\AA \AA{ }^{\circ}\right)$ of $C_{1}, C_{2}$ and $C_{3}{ }^{a}$

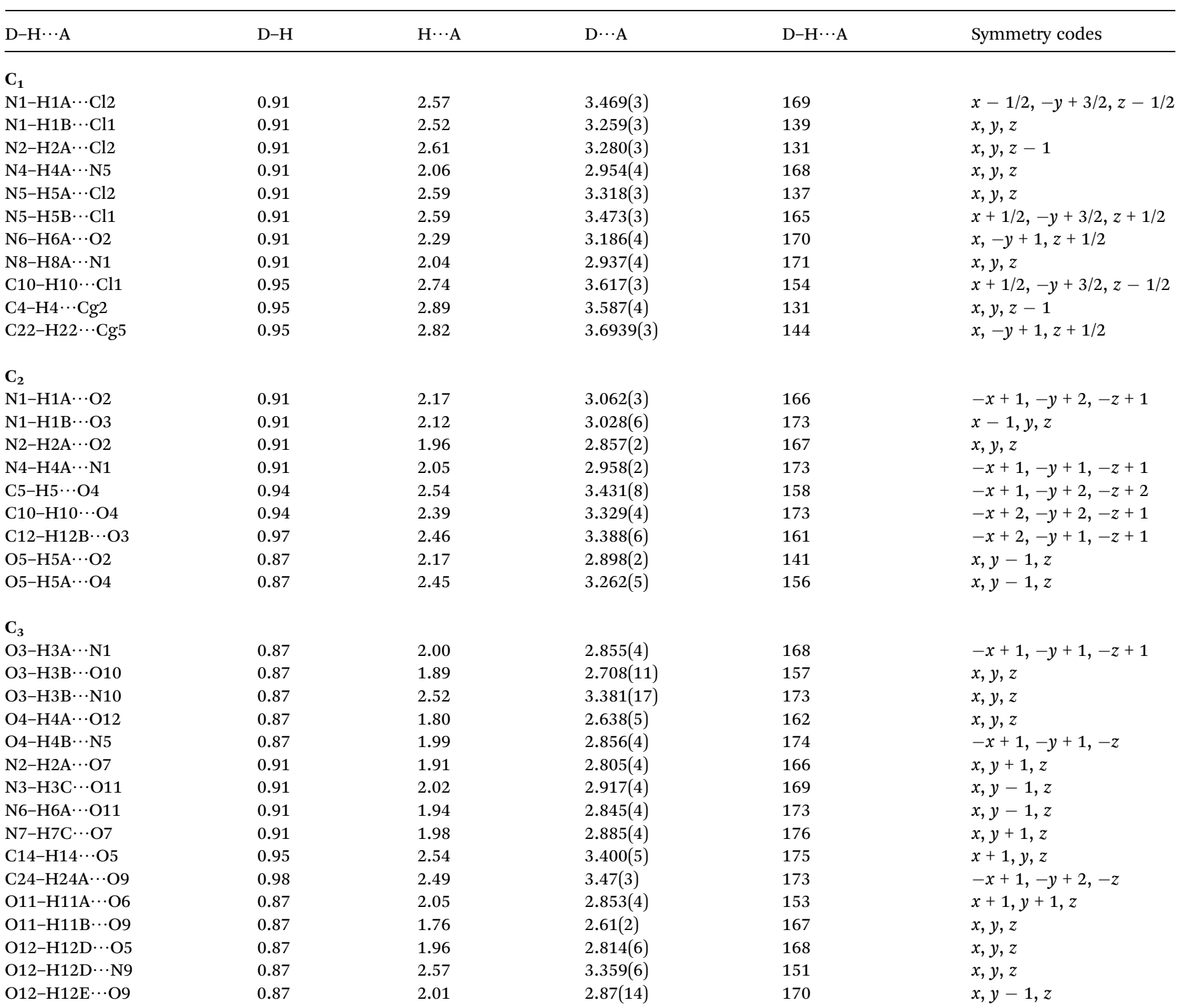

${ }^{a} \mathrm{C} 1$ : $\mathrm{Cg} 2$ and $\mathrm{Cg} 5$ are, respectively, the centroids of the $\mathrm{N} 7 / \mathrm{N} 8 / \mathrm{C} 32 / \mathrm{C} 22 / \mathrm{C} 21$ and $\mathrm{C} 1 \cdots \mathrm{C} 6$ rings. 
27853), Staphylococcus aureus (ATCC 25923) and Streptococcus fasciens (ATCC 29212) strains of bacteria.

\section{Experimental}

\subsection{General methods}

Melting points were measured using a Buchi B-545 digital capillary melting point apparatus and used without correction. Reactions were checked with TLC using aluminum sheets with silica gel 60 F254 from Merck. IR spectra were recorded on a PerkinElmer VERTEX 70 FT-IR spectrometer covering field 400-4000 $\mathrm{cm}^{-1}$. ${ }^{1} \mathrm{H}$ and ${ }^{13} \mathrm{C}$ NMR spectra were recorded in DMSO- $d_{6}$ on a Bruker spectrometer $(300 \mathrm{MHz})$. Mass spectra were collected using an API 3200 LC/MS/MS system, equipped with an ESI source. Chemical reagents were purchased from Fluka, Sigma and Aldrich chemicals. ${ }^{57} \mathrm{Fe}$ Mössbauer spectra were measured in transmission geometry at room temperature with a constant acceleration mode conventional spectrometer equipped with a $50 \mathrm{mCi}{ }^{57} \mathrm{Co}(\mathrm{Rh})$ source and a Reuter Stokes proportional counter. A microcrystalline sample of $\mathbf{C}_{3}$ was sealed in a Plexiglas sample holder. The spectrum was fitted using Recoil 1.05 Mössbauer Analysis software (Lagarec K., Rancourt D. G.: Recoil, Mössbauer spectral analysis software for Windows 1.0. Department of Physics, University of Ottawa, Canada (1998)). The isomer shift is given with respect to $\alpha$-Fe at room temperature. X-Ray powder diffraction patterns were recorded on a D8-Advance diffractometer (Bruker, Germany) working with a $\mathrm{Cu} \mathrm{K} \alpha$ radiation $(\lambda=1.5148 \AA)$.

\subsection{Synthesis}

2.2.1. Synthesis of (Z)-4-(2-oxopropylidene)-4,5-dihydro$\mathbf{1 H}$-1,5-benzodiazepin-2(3H)-one (3). A solution of dehydroacetic acid $(3.36 \mathrm{~g}, 0.02 \mathrm{~mol})$ and of $o$-phenylenediamine $(4.32 \mathrm{~g}$,
$0.04 \mathrm{~mol})$ in xylene $(80 \mathrm{~mL})$ was refluxed for $4 \mathrm{~h}$. Next, the precipitated product was filtered under reduced pressure and then recrystallized from ethanol. Yield: $75 \%(2.52 \mathrm{~g})$; m.p. $\left({ }^{\circ} \mathrm{C}\right)$ : 236-238; IR (ATR, $\left.\gamma\left(\mathrm{cm}^{-1}\right)\right): 1671,1607,1575 ;{ }^{1} \mathrm{H}$ NMR (300 MHz, DMSO- $\left.d_{6}, \delta(\mathrm{ppm})\right): 2.00\left(\mathrm{~s}, 3 \mathrm{H}, \mathrm{CH}_{3}\right) ; 3.00\left(\mathrm{~s}, 2 \mathrm{H}, \mathrm{CH}_{2}\right)$; $5.20(1 \mathrm{H}, \mathrm{s}) ; 7.10(4 \mathrm{H}, \mathrm{m})$; ESI-MS: $m / z=217[\mathrm{M}+\mathrm{H}]^{+}$.

2.2.2. Synthesis of $\mathrm{N}$-(2-aminophenyl)-2-(5-methyl-1Hpyrazol-3-yl)acetamide $\left(\mathbf{L}_{\mathbf{1}}\right)$. A mixture of $(Z)$-4-(2-oxopropylidene)-4,5-dihydro-1H-1,5-benzodiazepin-2(3H)-one (2 g, 0.92 $\mathrm{mmol})$ and stoichiometric amount of hydrazine hydrate $(0.46 \mathrm{~g}$, $0.92 \mathrm{mmol})$ in ethanol $(40 \mathrm{~mL})$ were refluxed for $2 \mathrm{~h}$. After concentration of the solvent volume to $20 \mathrm{~mL}$, the solution was allowed to stand; the precipitate formed was filtered off and then recrystallized from ethanol. Single crystals were obtained after recrystallization from ethanol. Yield: $80 \%(1.6 \mathrm{~g})$; m.p. $\left({ }^{\circ} \mathrm{C}\right)$ : 170-172; IR (ATR, $\left(\mathrm{cm}^{-1}\right)$ ): 3000-3400 (NH, $\left.\mathrm{NH}_{2}\right), 1737(\mathrm{C}=\mathrm{O})$, $1655(\mathrm{C}=\mathrm{N}) ;{ }^{1} \mathrm{H}$ NMR (300 MHz, DMSO- $\left.d_{6}, \delta(\mathrm{ppm})\right): 2.51(\mathrm{~s}, 3 \mathrm{H}$, $\left.\mathrm{CH}_{3}\right), 2.20\left(\mathrm{~s}, 2 \mathrm{H}, \mathrm{CH}_{2}\right), 4.86\left(\mathrm{~s}, 2 \mathrm{H}, \mathrm{NH}_{2}\right), 5.94\left(\mathrm{~s}, 1 \mathrm{H}, \mathrm{H}_{\text {pyrazole }}\right)$, 6.52-7.16 (m, 5H, $\left.\mathrm{H}_{\mathrm{Ar}}\right), 9.25\left(\mathrm{~s}, 1 \mathrm{H}, \mathrm{N}-\mathrm{H}_{\text {amide }}\right), 12.24(\mathrm{~s}, 1 \mathrm{H}$, $\mathrm{NH}_{\text {pyrazole }}$ ); ESI-MS: $m / z=231[\mathrm{M}+\mathrm{H}]^{+}$.

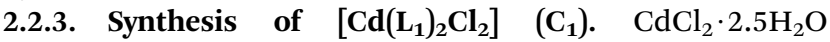
(100 mg, $0.44 \mathrm{mmol}, 1$ eq.) was dissolved in water $(10 \mathrm{~mL})$ and added to a solution of $\mathbf{L}_{\mathbf{1}}(200 \mathrm{mg}, 0.87 \mathrm{mmol}, 2$ eq.) in ethanol (15 mL). The resulting light yellow solution was left at room temperature. Colorless column-like single crystals were obtained by slow evaporation of a clear light yellow solution of the reaction mixture after $48 \mathrm{~h}$. Yield $=88 \%(490 \mathrm{mg})$; FT-IR (ATR, $\left.\left(\mathrm{cm}^{-1}\right)\right)$ : 3391-3291 (NH, $\left.\mathrm{NH}_{2}\right), 3117-2866(\mathrm{CH}), 1746(\mathrm{C}=\mathrm{O})$, $1653(\mathrm{C}=\mathrm{N}), 1625,1604,1586(\mathrm{C}=\mathrm{C}), 608(\mathrm{Cd}-\mathrm{Cl}), 541(\mathrm{Cd}-\mathrm{N})$, 404 (Cd-O); ESI-MS: $m / z=607.1030[\mathrm{M}-\mathrm{Cl}+\mathrm{H}]^{+}$for $\mathrm{C}_{24} \mathrm{H}_{28^{-}}$ $\mathrm{CdCl}_{2} \mathrm{~N}_{8} \mathrm{O}_{2}$ in $\mathrm{MeOH}$.

2.2.4. Synthesis of $\left[\mathrm{Cu}\left(\mathrm{L}_{1}\right)_{2}\left(\mathrm{C}_{2} \mathrm{H}_{5} \mathrm{OH}\right)_{2}\right] \cdot\left(\mathrm{NO}_{3}\right)_{2} \quad\left(\mathrm{C}_{2}\right)$. $\mathrm{Cu}\left(\mathrm{NO}_{3}\right)_{2} \cdot 3 \mathrm{H}_{2} \mathrm{O}(110 \mathrm{mg}, 0.46 \mathrm{mmol}, 1$ eq.) was dissolved in

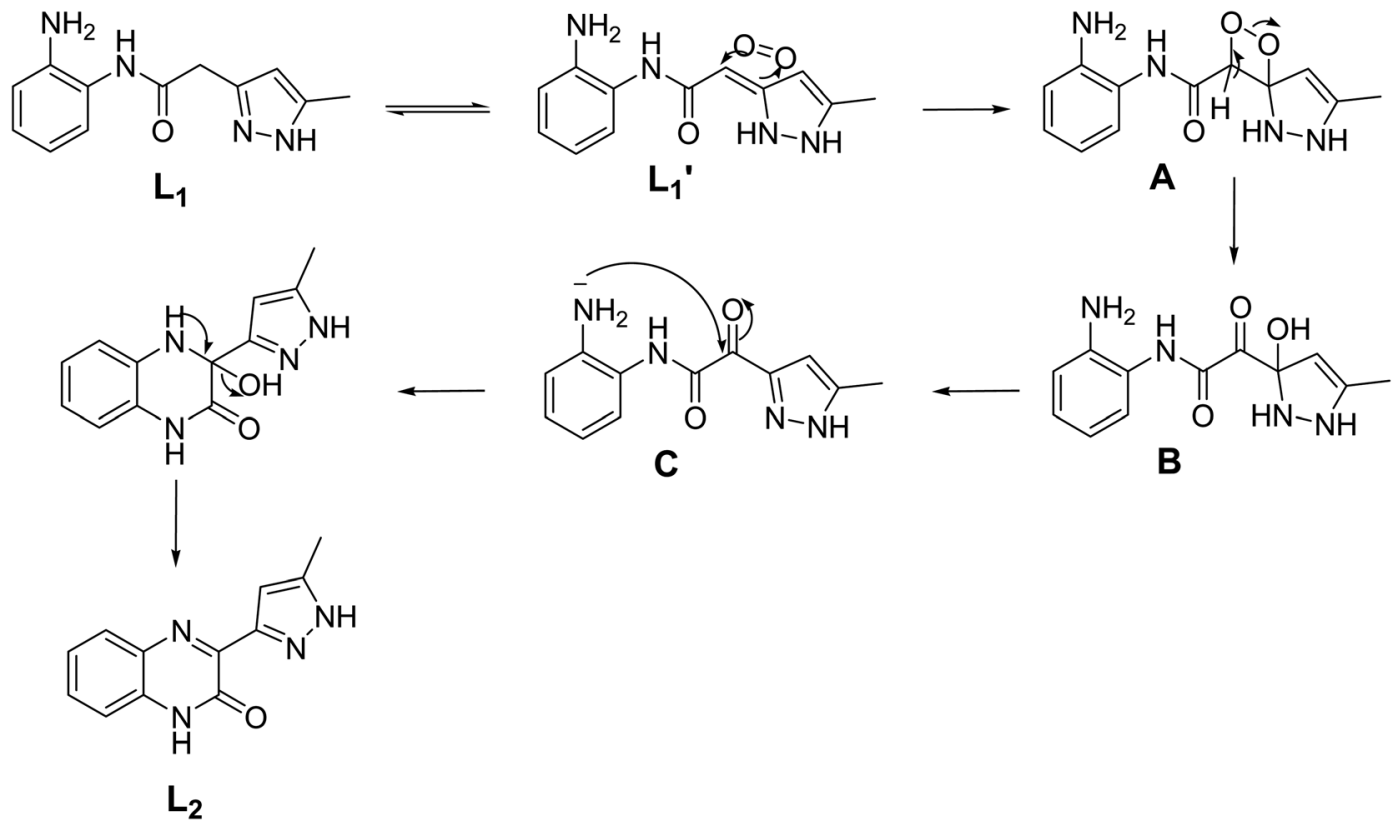

Scheme 2 Plausible reaction mechanism for the formation of $L_{2}$. 
water $(10 \mathrm{~mL})$ and added to a solution of $\mathbf{L}_{\mathbf{1}}(200 \mathrm{mg}, 0.87 \mathrm{mmol}$, 2 equiv.) in ethanol $(15 \mathrm{~mL})$. The resulting solution was stirred and warmed slightly. The light green precipitate was filtered and then recrystallized from ethanol and left at room temperature. Light green single crystals were obtained by slow evaporation of the reaction mixture after $24 \mathrm{~h}$. Yield: $90 \%(580 \mathrm{mg})$; FT-IR (ATR, $\left.\left(\mathrm{cm}^{-1}\right)\right)$ : 3398-3217 $\left(\mathrm{NH}, \mathrm{NH}_{2}\right), 3121-2905(\mathrm{CH})$, $1746(\mathrm{C}=\mathrm{O}), 1614(\mathrm{C}=\mathrm{N}), 1554,1499,1453(\mathrm{C}=\mathrm{C}), 427(\mathrm{Cu}-\mathrm{N})$; ESI-MS: $m / z=615.2382[\mathrm{M}+\mathrm{H}]^{+}$for $\mathrm{C}_{28} \mathrm{H}_{40} \mathrm{CuN}_{8} \mathrm{O}_{4}$ in $\mathrm{MeOH}$.

2.2.5. Synthesis of $\left[\mathrm{Fe}\left(\mathrm{L}_{2}\right)_{2}\left(\mathrm{H}_{2} \mathrm{O}\right)_{2}\right]\left(\mathrm{NO}_{3}\right)_{2} \cdot 2 \mathrm{H}_{2} \mathrm{O} \quad\left(\mathrm{C}_{3}\right)$. $\mathrm{Fe}\left(\mathrm{NO}_{3}\right)_{3} \cdot 9 \mathrm{H}_{2} \mathrm{O}(180 \mathrm{mg}, 0.45 \mathrm{mmol}, 1$ eq.) was dissolved in water $(10 \mathrm{~mL})$ and added to a solution of $\mathbf{L}_{\mathbf{1}}(200 \mathrm{mg}$, $0.87 \mathrm{mmol}, 2$ eq.) dissolved in ethanol $(15 \mathrm{~mL})$. The resulting red solution was stirred and warmed slightly, and left at $10{ }^{\circ} \mathrm{C}$. Red orange single crystals were obtained by slow evaporation of the reaction mixture after $24 \mathrm{~h}$, and filtrated. Yield: $45 \%$ $(280 \mathrm{mg})$; FT-IR (ATR, $\left.\left(\mathrm{cm}^{-1}\right)\right): 3198-2860(\mathrm{CH}), 1663(\mathrm{C}=\mathrm{O})$, $1624(\mathrm{C}=\mathrm{N}), 1575,1537,1518(\mathrm{C}=\mathrm{C}), 505(\mathrm{Fe}-\mathrm{N})$; ESI-MS: $m / z$ $=566.1096[\mathrm{M}+\mathrm{Na}]^{+}$for $\mathrm{C}_{24} \mathrm{H}_{24} \mathrm{FeN}_{8} \mathrm{O}_{4}$ in $\mathrm{MeOH}$. When the reaction was carried out at $40{ }^{\circ} \mathrm{C}$, a black powder precipitated which was filtrated and analyzed by X-ray powder diffraction and ${ }^{57}$ Fe Mössbauer spectroscopy. From this black powder, red orange crystals could be isolated, presenting the same structure as $\mathbf{C}_{3}$.

\subsection{X-ray analysis}

$\mathrm{X}$-ray single-crystal data were collected on single crystals using Mo $\mathrm{K} \alpha(\lambda=0.7107 \mathrm{~A})$ radiation on a Bruker SMART APEX diffractometer equipped with CCD area detector. Unit cell refinement data reduction (SAINT) and structure solution as well as refinement (SHELXTL) ${ }^{45}$ were carried out using the software package of SMART APEX. The structures of $\mathbf{C}_{\mathbf{1}}, \mathbf{C}_{\mathbf{2}}$ and $\mathbf{C}_{3}$ were solved by direct method and refined in a routine manner. In both structures, non-hydrogen atoms were treated anisotropically. Molecular graphics were generated by using the softwares MERCURY 3.9 (ref. 46) and POV-Ray. The details of the X-ray crystal data and the structure solution as well as the refinement are given in Table 1. CCDC 2095071-2095073 for $\mathbf{C}_{\mathbf{1}}$, $\mathbf{C}_{2}$ and $\mathbf{C}_{3}$, respectively contain the supplementary crystallographic data for these compounds.

\subsection{Antibacterial activity}

The antibacterial activity of the synthesized compounds was determined according to the method described in our previous work. ${ }^{43}$

\section{Result and discussion}

\subsection{Synthesis of pyrazole-acetamide ligands $L_{1}$}

Our strategy was to develop a simple, high-yield, synthetic procedure in a few steps to prepare the desired acetamide derivative. The development of the synthesis of $\mathbf{L}_{\mathbf{1}}$ is given in Scheme 1 . The major product $3^{47}$ was produced in good yield by condensation of $o$-phenylenediamine with dehydroacetic acid (DHA) in refluxing xylene for $4 \mathrm{~h}$. The second step consists in the condensation of a stoichiometric amount of hydrazine monohydrate with the benzodiazepine compound 3 in refluxing ethanol for $2 \mathrm{~h}$ to give the ligand pyrazole-acetamide $\mathbf{L}_{\mathbf{1}}$ in good yield $^{48}$ (Scheme 1).

\subsection{Synthesis of coordination complexes $C_{1}, C_{2}$ and $C_{3}$}

The three coordination complexes $\left[\mathrm{Cd}\left(\mathbf{L}_{\mathbf{1}}\right)_{2} \mathrm{Cl}_{2}\right]\left(\mathbf{C}_{\mathbf{1}}\right),\left[\mathrm{Cu}\left(\mathbf{L}_{\mathbf{1}}\right)_{2}(-\right.$ $\left.\left.\mathrm{C}_{2} \mathrm{H}_{5} \mathrm{OH}\right)_{2}\right]\left(\mathrm{NO}_{3}\right)_{2} \quad\left(\mathbf{C}_{2}\right)$ and $\left[\mathrm{Fe}\left(\mathbf{L}_{2}\right)_{2}\left(\mathrm{H}_{2} \mathrm{O}\right)_{2}\right]\left(\mathrm{NO}_{3}\right)_{2} \cdot 2 \mathrm{H}_{2} \mathrm{O} \quad\left(\mathbf{C}_{3}\right)$ were obtained as single crystals after recrystallization from ethanol during the reaction carried out in an aqueous ethanolic
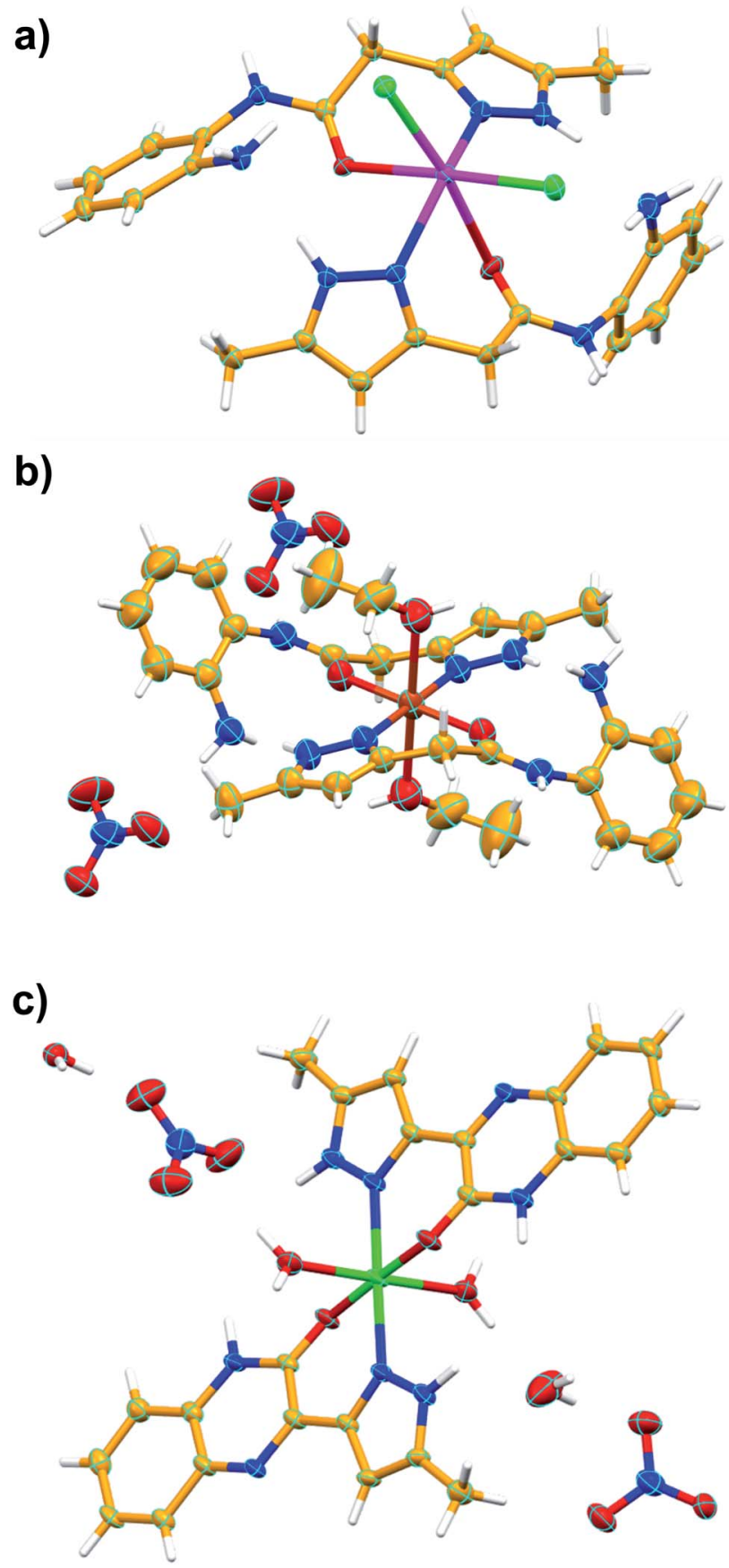

Fig. 2 Asymmetric unit of $C_{1}(a), C_{2}$ (b) and $C_{3}$ (c). Color codes: $C-$ orange, $\mathrm{N}$ - blue, $\mathrm{H}$ - white, $\mathrm{Cd}$ - Magenta, $\mathrm{Cu}$ - dark orange, $\mathrm{Fe}-$ green, $\mathrm{O}-$ red, $\mathrm{Cl}$ - green. 
solution involving pyrazole acetamide $\mathbf{L}_{\mathbf{1}}$ and $\mathrm{Cd}(\mathrm{II}), \mathrm{Cu}(\mathrm{II})$ and $\mathrm{Fe}(\mathrm{III})$ (metal/ligand ratio $1: 2$ ), respectively (Table 2 ).

While classic coordination occurred for $\mathbf{L}_{\mathbf{1}}$ with cadmium and copper, an unexpected oxidation reaction followed by an intramolecular cyclization of the formed intermediate was presumably observed when iron nitrate was used as chelating agent. Thus, the iron(II) complex $\mathbf{C}_{3}$ was synthesized in low yield by the reaction of $\mathrm{Fe}\left(\mathrm{NO}_{3}\right)_{3} \cdot 9 \mathrm{H}_{2} \mathrm{O}$ with $\mathbf{L}_{\mathbf{1}}$ in a $1: 2$ molar ratio using ethanol as a solvent. The low yield of the compound is attributed to the involvement of the $\mathbf{L}_{\mathbf{1}}$ ligand in the redox reaction with $\mathrm{Fe}(\mathrm{III})$ ion, where the $\mathrm{Fe}(\mathrm{III})$ ion was reduced to $\mathrm{Fe}(\mathrm{II})$ ion. The $\mathrm{Fe}(\mathrm{II})$ ion produced was complexed with the ligand $\mathbf{L}_{2}$ formed by the oxidation of $\mathbf{L}_{\mathbf{1}}$ (Scheme 2). The first $\mathrm{Fe}(\mathrm{III})$ promoted in situ oxidation of a thiazoline-2-thione to the corresponding hetero-disulphide with concomitant coordination to $\mathrm{Fe}$ (II) was reported by Raper et al., ${ }^{49}$ Several studies have been conducted mainly to characterize the products of reactions between nitrogen-containing ligands and $\mathrm{Fe}(\mathrm{III})$ ions under aerobic conditions. ${ }^{50-53}$ The presence of the electronwithdrawing groups increases the reduction potential of the $\mathrm{Fe}^{3+}+\mathrm{e}^{-} \leftrightarrow \mathrm{Fe}^{2+}$ redox couple, making the reduction product thermodynamically more stable. ${ }^{54}$
A plausible mechanism (Scheme 2) is proposed to explain the original transformation of pyrazole acetamide $\mathbf{L}_{\mathbf{1}}$ into the new ligand $\mathbf{L}_{2}$. Thus, the participation of the ligand $\mathbf{L}_{\mathbf{1}}$ in redox reaction with $\mathrm{Fe}(\mathrm{III})$ ion, where $\mathrm{Fe}(\mathrm{III})$ ion was reduced to $\mathrm{Fe}(\mathrm{II})$ ion and $\mathbf{L}_{\mathbf{1}}$ was oxided to $\mathbf{L}_{\mathbf{1}}{ }^{\prime}$, is proposed. Afterwards, air oxygen reacted with the carbon-carbon double bond of the tautomeric form $\mathbf{L}_{\mathbf{1}}{ }^{\prime}$ affording spiro oxetane pyrazole $\mathbf{A}$ which undergoes a ring opening of the oxetane moiety under the effect of a base to lead to the hydroxy pyrazoline B. The latter compound aromatizes by the loss of a water molecule to give the ketonic amide $\mathbf{C}$ which undergoes an intramolecular cyclization to afford after a loss of a water molecule pyrazolyl quinoxaline acting as coordination compound towards $\mathrm{Fe}(\mathrm{II})$ ion produced by reduction of $\mathrm{Fe}(\mathrm{III})$. It should be noted that a similar oxidation reaction has already been observed in our previous work on 1,2,4-triazolo pyrimidines. ${ }^{43}$

3.3. Description of the crystal structures of the complexes $\left[\mathrm{Cd}\left(\mathrm{L}_{1}\right)_{2} \mathrm{Cl}_{2}\right]\left(\mathrm{C}_{1}\right),\left[\mathrm{Cu}\left(\mathrm{L}_{1}\right)_{2}\left(\mathrm{C}_{2} \mathrm{H}_{5} \mathrm{OH}\right)_{2}\right]\left(\mathrm{NO}_{3}\right)_{2}\left(\mathrm{C}_{2}\right)$ and $\left[\mathrm{Fe}\left(\mathrm{L}_{2}\right)_{2}\left(\mathrm{H}_{2} \mathrm{O}\right)_{2}\right]\left(\mathrm{NO}_{3}\right)_{2} \cdot 2 \mathrm{H}_{2} \mathrm{O}\left(\mathrm{C}_{3}\right)$

The crystal structures of $\mathbf{C}_{\mathbf{1}}, \mathbf{C}_{\mathbf{2}}$ and $\mathbf{C}_{\mathbf{3}}$ are shown in Fig. 2 . Crystallization of all the three coordination compounds was

\section{a)}

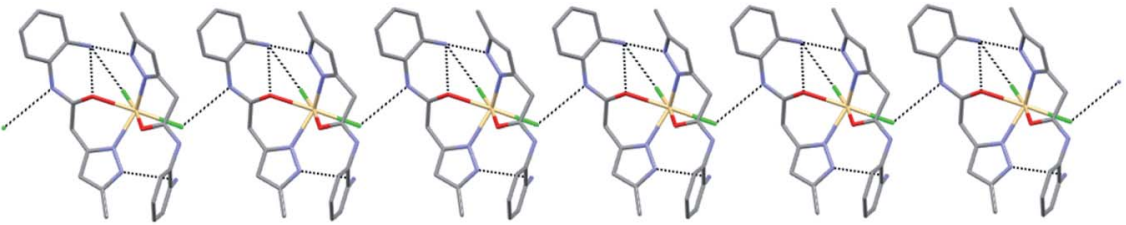

b)

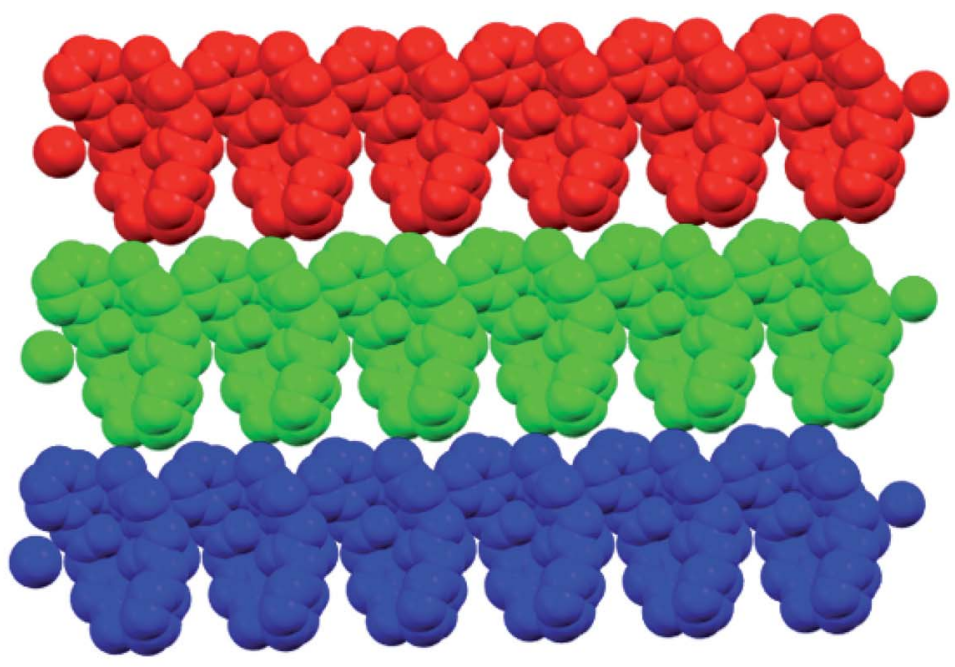

\section{c)}

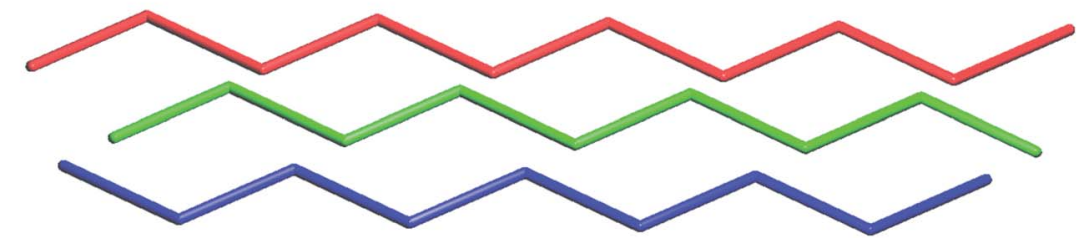

Fig. 3 Crystal structure illustration of $\mathrm{C}_{1}$, (a) $1 \mathrm{D}$ hydrogen bonded chains (black dotted lines represent the $\mathrm{N}-\mathrm{H} \cdots \mathrm{Cl}$ interactions), (b) parallel packing of 1D chains (view along crystallographic axis 'b'), (c) TOPOS view of the parallel packing of 1D chains. 
obtained by reaction of the ligand $\mathbf{L}_{1}$ (for $\mathbf{C}_{\mathbf{1}}$ and $\mathbf{C}_{2}$ ) or $\mathbf{L}_{2}$ (for $\mathbf{C}_{3}$ ) and metal salts in aqueous ethanolic solution (metal: ligand $=1: 2$ ) by slow evaporation.

3.3.1. $\left[\mathbf{C d}\left(\mathbf{L}_{1}\right)_{2} \mathbf{C l}_{2}\right]\left(\mathbf{C}_{1}\right)$. Colorless column-like single crystals of $\mathbf{C}_{\mathbf{1}}$ crystalized in the monoclinic space group Cc (Table 1 ). The asymmetric unit contains one crystallographically unique Cd(II) ion, two molecules of ligand $\mathbf{L}_{\mathbf{1}}$ and two chloride anions. The Cd(II) metal center showed distorted octahedral geometry $\left[\angle \mathrm{N}-\mathrm{Cd}-\mathrm{Cl}=100.78(7)-106.73(7)^{\circ} ; \quad \angle \mathrm{N}-\mathrm{Cd}-\mathrm{O}=77.13(8)-\right.$ $78.18(8)^{\circ} ; \angle \mathrm{Cl}-\mathrm{Co}-\mathrm{Cl}=100.22(3)^{\circ} ; \angle \mathrm{O}-\mathrm{Cd}-\mathrm{O}=86.72(10)^{\circ}$; $\left.\angle \mathrm{O}-\mathrm{Cd}-\mathrm{Cl}=83.69(6)^{\circ}\right]$ in which the coordination sites are occupied by two chloride anions, and $\mathrm{N}$ atoms of pyrazole and $\mathrm{O}$ atoms of amide of the ligand $\mathbf{L}_{\mathbf{1}}$. The equatorial coordination sites of $\mathrm{Cd}$ (II) are occupied with the two $\mathrm{N}$ atoms and one $\mathrm{O}$ atom of the pyrazole and amide functionalities of the ligand $\mathbf{L}_{\mathbf{1}}$, respectively, and one $\mathrm{Cl}^{-}$anion, and the axial position are coordinated to one $\mathrm{Cl}^{-}$anion and one $\mathrm{O}$ atom of amide moiety of $\mathbf{L}_{\mathbf{1}}$. Basically, the non-planar ligand $\mathbf{L}_{\mathbf{1}}$ [torsion angle between the planes of the aromatic rings $=47.84(2)$ and $60.33(8)^{\circ}$ for crystallographically independent ligands] coordinates to $\mathrm{Cd}(\mathrm{II})$ in an $\mathrm{N}$, O-chelating mode, generating the six-membered chelate ring as expected. Such chelation was strongly supported by strong intramolecular hydrogen bonding involving amino group of $\mathbf{L}_{\mathbf{1}}$ with the metal bound $\mathrm{Cl}^{-}$anion $[\mathrm{N}-\mathrm{H} \cdots \mathrm{Cl}=$ 3.259(3) $\mathrm{A}, \angle \mathrm{N}-\mathrm{H}-\mathrm{Cl}=139^{\circ}$ ], $\mathrm{O}$ atom of amide functionality of $\mathbf{L}_{\mathbf{1}}\left[\mathrm{N}-\mathrm{H} \cdots \mathrm{O}=2.934(3) \AA, \angle \mathrm{N}-\mathrm{H}-\mathrm{O}=109^{\circ}\right]$ and $\mathrm{N}$ atom of pyrazole $\left[\mathrm{N}-\mathrm{H} \cdots \mathrm{N}=2.937(4) \AA, \angle \mathrm{N}-\mathrm{H}-\mathrm{N}=171^{\circ}\right]$ resulted in a four-membered, six-membered and five-membered rings, respectively. Moreover, supramolecular assembly in the crystal structure of $\mathbf{C}_{\mathbf{1}}$ is mainly driven by $\mathrm{N}-\mathrm{H} \cdots \mathrm{Cl}$ hydrogen-bonding interactions comprising $\mathrm{N}-\mathrm{H}$ of the amide moiety of $\mathbf{L}_{\mathbf{1}}$ and metal bound $\mathrm{Cl}^{-}$anion $[\mathrm{N}-\mathrm{H} \cdots \mathrm{Cl}=3.280(3) \AA, \angle \mathrm{N}-\mathrm{H}-\mathrm{Cl}=$ $\left.131^{\circ}\right]$, resulting in a one-dimensional (1D) hydrogen bonded chain structure. Such chains are further assembled in parallel fashion with the support of various van der Waals interactions (Fig. 3).

3.3.2. $\left[\mathrm{Cu}\left(\mathrm{L}_{1}\right)_{2}\left(\mathrm{C}_{2} \mathrm{H}_{5} \mathrm{OH}\right)_{2}\right]\left(\mathrm{NO}_{3}\right)_{2}\left(\mathrm{C}_{2}\right)$. Light green colored single crystals of $\mathbf{C}_{2}$ belong to triclinic centrosymmetric space group $P \overline{1}$. The asymmetric unit contains one-half of $\mathrm{Cu}$ (II) ion, one full molecule of ligand (coordinated to the metal center $\mathrm{Cu}(\mathrm{II})$ through $\mathrm{N}$ atom of pyrazole and $\mathrm{O}$ atom of amide functionality of $\mathbf{L}_{\mathbf{1}}$ in a chelate fashion), one molecule of ethanol (also coordinated to $\mathrm{Cu}^{2+}$ ) and one nitrate counter anion. Thus the entire octahedral coordination complex is generated by the inversion center of symmetry located on the metal ion $\mathrm{Cu}^{2+}$. The $\mathrm{Cu}(\mathrm{II})$ metal center showed slightly distorted octahedral geometry $\left[\angle \mathrm{N}-\mathrm{Cu}-\mathrm{O}=89.48(7)-90.52(7)^{\circ} ; \angle \mathrm{O}-\mathrm{Cu}-\mathrm{O}=89.40(6)-\right.$ $\left.90.60(6)^{\circ}\right]$ in which the equatorial coordination positions of $\mathrm{Cu}(\mathrm{II})$ are occupied by the $\mathrm{O}$ and $\mathrm{N}$ atoms of $\mathbf{L}_{\mathbf{1}}$ through its amide and pyrazole moieties resulted in $\mathrm{N}, \mathrm{O}$-chelated six membered ring, and axial positions of the metal center are coordinated to the $\mathrm{O}$ atoms of ethanol (EtOH). As expected the ligand showed nonplanar geometry, revealed from the torsion angle $\left[68.62(6)^{\circ}\right]$ between the planes of the aromatic rings. The amine and amide $\mathrm{N}-\mathrm{H}$ of the coordination complex form hydrogen bonding with $\mathrm{O}$ atoms of the nitrate anion $[\mathrm{N}-\mathrm{H} \cdots \mathrm{O}=3.028(7) \AA, \angle \mathrm{N}-\mathrm{H}-\mathrm{O}=$ $\left.173^{\circ}\right]$; the nitrate anion also involved in bifurcated hydrogen bonding with $\mathrm{N}-\mathrm{H}$ of amine $[\mathrm{N}-\mathrm{H} \cdots \mathrm{O}=2.857(2) \AA, \angle \mathrm{N}-\mathrm{H}-\mathrm{O}=$ $\left.167^{\circ}\right]$ and $\mathrm{O}-\mathrm{H}$ of metal bound ethanol molecule $[\mathrm{O}-\mathrm{H} \cdots \mathrm{O}=$ $2.898(2) \AA, \angle \mathrm{O}-\mathrm{H}-\mathrm{O}=141^{\circ}$ ] resulted in $R_{1}^{2}(9)$ ring (Fig. $4 \mathrm{a}$ ). Supramolecular assembly in the crystal structure of $\mathbf{C}_{2}$ is mainly directed by intermolecular $\mathrm{N}-\mathrm{H} \cdots \mathrm{O}$ and $\mathrm{O}-\mathrm{H} \cdots \mathrm{O}$ hydrogenbonding interactions involving the nitrate anion with amide, metal bound ethanol and amine resulted in three synthons

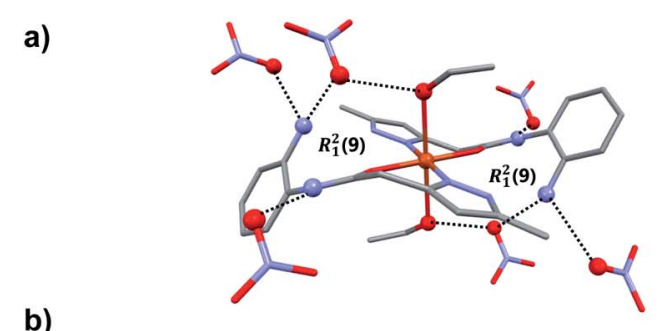

b)

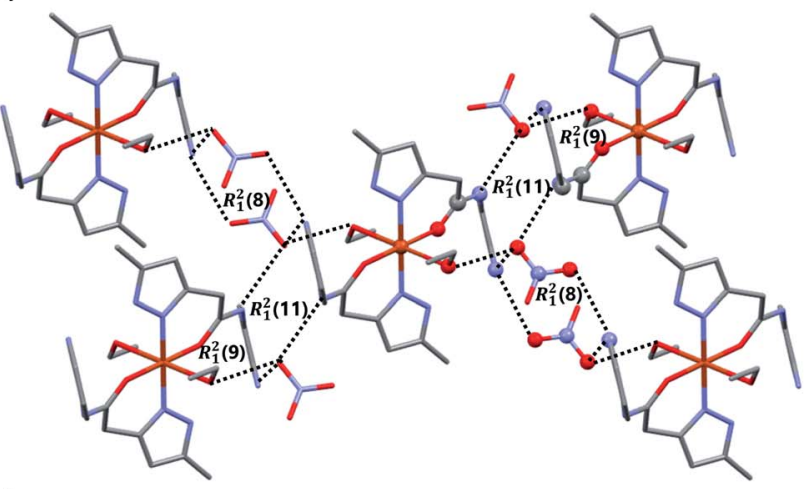

c)

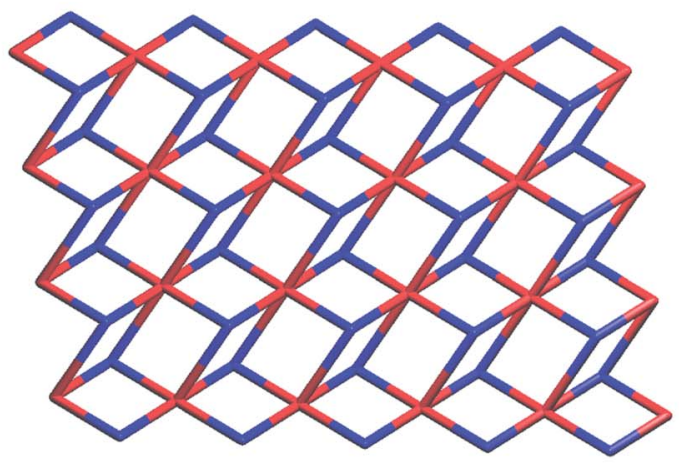

d)

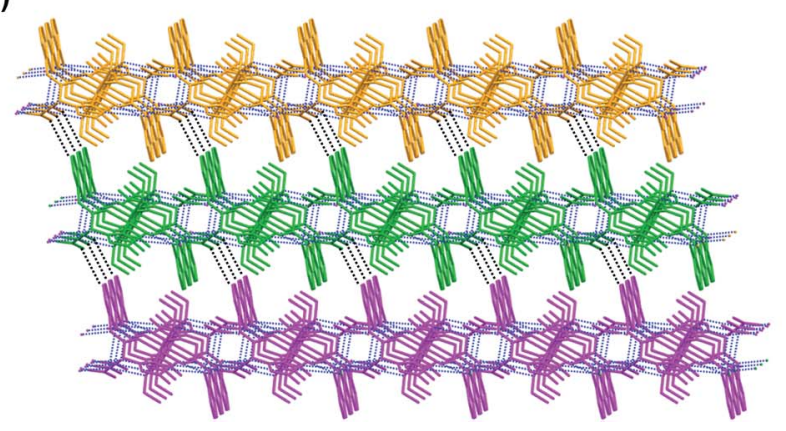

Fig. 4 Crystal structure illustration of $\mathrm{C}_{2}$, (a) the $\mathrm{N}-\mathrm{H} \cdots \mathrm{O}$ and $\mathrm{O}-\mathrm{H} \cdots \mathrm{O}$ hydrogen bonding in $\mathrm{C} 2$ displaying the $R_{1}^{2}(9)$ ring, (b) various hydrogen bonding and the view of $R_{1}^{2}(11), R_{1}^{2}(9)$ and $R_{1}^{2}(8)$ rings, (c) TOPOS view of $2 \mathrm{D}$ hydrogen bonded sheet, (d) the stacking of $2 \mathrm{D}$ layers along crystallographic axis 'a' (adjacent 2D layers are shown in orange, green and magenta). 
having graph-sets of $R_{1}^{2}(11), R_{1}^{2}(9)$ and $R_{1}^{2}(8)$ (Fig. $\left.4 \mathrm{~b}\right)$. Selfassembly through these three synthons lead to the formation of a two-dimensional (2D) hydrogen bonded sheet structure. If the discrete $\left[\mathrm{Cu}\left(\mathbf{L}_{1}\right)_{2}(\mathrm{EtOH})_{2}\right]$ complex, and nitrate anions are taken as nodes, 2D hydrogen bonded network in this coordination compound can be simplified to a $2 \mathrm{D}(3,6)$-connected $\mathrm{kgd}$ net with a point (Schläfli) symbol of $\left\{4^{3}\right\}_{2}\left\{4^{6} \cdot 6^{6} \cdot 8^{3}\right\}$ (Fig. 4c). Such 2D layers are stack up each other along crystallographic axis ' $a$ ' with the support of $\mathrm{C}-\mathrm{H} \cdots \mathrm{O}$ hydrogen bonding involving aromatic $\mathrm{C}-\mathrm{H}$ and $\mathrm{O}$ atom of nitrate anion $[\mathrm{C}-\mathrm{H} \cdots \mathrm{O}=3.431(8)$ $\AA$, $\angle \mathrm{C}-\mathrm{H}-\mathrm{O}=158^{\circ}$ ] (Fig. $4 \mathrm{~d}$ ).

3.3.3. $\left[\mathrm{Fe}\left(\mathrm{L}_{2}\right)_{2}\left(\mathrm{H}_{2} \mathrm{O}\right)_{2}\right]\left(\mathrm{NO}_{3}\right)_{2} \cdot 2 \mathrm{H}_{2} \mathrm{O} \quad\left(\mathrm{C}_{3}\right)$. Orange colored single crystals of $\mathbf{C}_{3}$ got crystalized in the centrosymmetric triclinic space group $P \overline{1}$ (Table 1$)$. The asymmetric unit comprises of one $\mathrm{Fe}\left(\right.$ II) ion, two molecules of ligand $\mathbf{L}_{2}$, two water molecules (both water and $\mathbf{L}_{2}$ are coordinated to $\mathrm{Fe}(\mathrm{II})$ ), two nitrate counter anions and two solvated water molecules. The Fe(II) metal center showed distorted octahedral geometry $\left[\angle \mathrm{O}-\mathrm{Fe}-\mathrm{O}=88.91(11)-91.62(11)^{\circ} ; \quad \angle \mathrm{O}-\mathrm{Fe}-\mathrm{N}=84.56(11)-\right.$ $\left.97.20(11)^{\circ}\right]$ in which the equatorial and axial coordination sites are occupied by ligand $\mathbf{L}_{2}$ and water molecules, respectively. In the crystal structure, the ligand $\mathbf{L}_{2}$ showed slightly non-planar structure in which the torsion angle between the plane of quinoxalinone and pyrazole is $11.43-13.11^{\circ}$. The $\mathrm{O}$ atom of quinoxalinone and $\mathrm{N}$ atom of pyrazole moieties of $\mathbf{L}_{2}$ are coordinated to the $\mathrm{Fe}(\mathrm{II})$ resulted in a N,O-chelated six membered ring. The hydrogen bonding interactions of nitrate anions with solvated water molecule $[\mathrm{N}-\mathrm{H} \cdots \mathrm{O}=2.885(5) \AA, \angle \mathrm{N}-\mathrm{H}-\mathrm{O}=$ $\left.177^{\circ} ; \mathrm{O}-\mathrm{H} \cdots \mathrm{O}=2.813(5)-2.87(3) \AA, \angle \mathrm{O}-\mathrm{H}-\mathrm{O}=168-170^{\circ}\right]$ and nitrate $\cdots \pi$ interaction $[3.454(6) \AA]$ of nitrate with pyrazole ring of metal coordinated $\mathbf{L}_{2}$ resulted in an twelve membered ring which contains the four donor and acceptor atoms with a graphset symbol $R_{4}^{4}(12)$ (Fig. 5a). This synthon is connected to the discrete $\left[\mathrm{Fe}\left(\mathbf{L}_{2}\right)_{2}\left(\mathrm{H}_{2} \mathrm{O}\right)_{2}\right]$ complex unit node through nitrate anions, metal bound water molecule and quinoxalinone moiety via $\mathrm{N}-\mathrm{H} \cdots \mathrm{O}$ and $\mathrm{O}-\mathrm{H} \cdots \mathrm{O}$ interactions $[\mathrm{N}-\mathrm{H} \cdots \mathrm{O}=2.805(4) \AA$, $\left.\angle \mathrm{N}-\mathrm{H}-\mathrm{O}=166^{\circ} ; \mathrm{O}-\mathrm{H} \cdots \mathrm{O}=2.708(12) \AA, \angle \mathrm{O}-\mathrm{H}-\mathrm{O}=157^{\circ}\right]$. The same synthon is further assembled with the neighboring $\left[\mathrm{Fe}\left(\mathbf{L}_{2}\right)_{2}\left(\mathrm{H}_{2} \mathrm{O}\right)_{2}\right]$ complex unit node through another twelve membered ring having a graph-set of $R_{4}^{4}(12) \mathrm{N}-\mathrm{H} \cdots \mathrm{O}[\mathrm{N}-\mathrm{H} \cdots \mathrm{O}$ $\left.=2.845(4) \AA, \angle \mathrm{N}-\mathrm{H}-\mathrm{O}=173^{\circ}\right]$ and $\mathrm{O}-\mathrm{H} \cdots \mathrm{O}[\mathrm{O}-\mathrm{H} \cdots \mathrm{O}=$ 2.61(3)-2.87(3) $\left.\AA, \angle \mathrm{O}-\mathrm{H}-\mathrm{O}=162-170^{\circ}\right]$ hydrogen bonding involving nitrate anions, solvated water molecules, quinoxalinone $\mathrm{N}-\mathrm{H}$ and $\mathrm{Fe}(\mathrm{II})$ coordinated water molecule (Fig. 5a). The hydrogen bonding interactions through these two synthons resulted in the self-assembly of $\mathrm{C} 2$ along crystallographic axis " $b$ " lead to the formation of one-dimensional hydrogen bonded chain (Fig. 5a). The self-assembly further follow through these
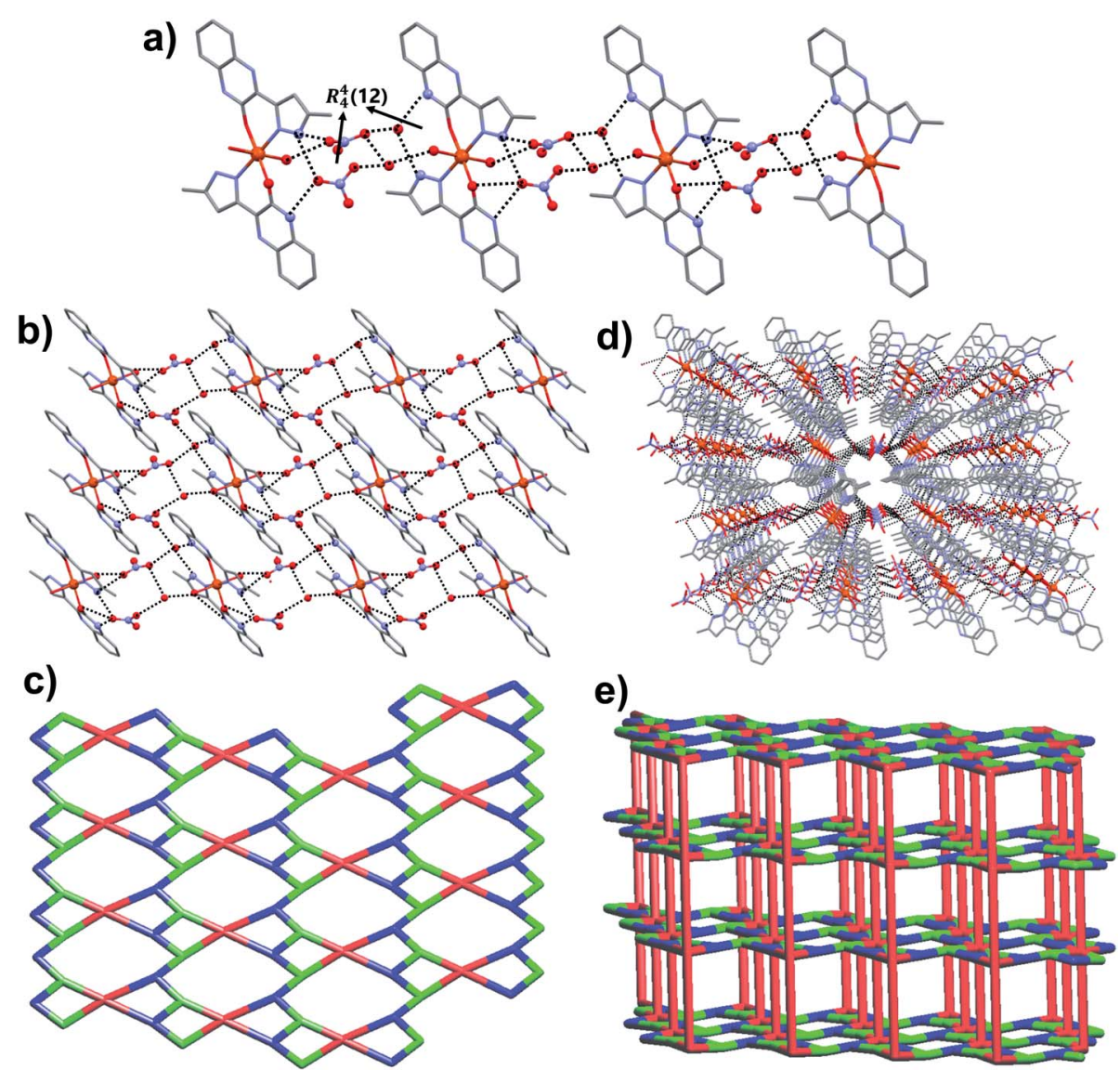

Fig. 5 Crystal structure illustration of $C_{3}$, (a) $1 \mathrm{D}$ chain self-assembly of $\mathrm{C}_{3}$ through $R_{4}^{4}(12)$ rings via various hydrogen bonding, (b) $2 \mathrm{D}$ hydrogen bonded assembly, (c) TOPOS view of 2D hydrogen bonded network, (d) 3D hydrogen bonded network, (e) TOPOS view of 3D [32.6-c]-connected net. 
two twelve membered ring synthons along crystallographic axis " $a$ " resulted in a 2D hydrogen bonded sheet network structure (Fig. 5b and c). Interestingly, such 2D network structure further self-assembled through $\mathrm{O}-\mathrm{H}-\mathrm{N}$ hydrogen bonding $[\mathrm{O}-\mathrm{H} \cdots \mathrm{N}=$ 2.856(4) $\AA$, $\left.\angle \mathrm{O}-\mathrm{H}-\mathrm{N}=174^{\circ}\right]$ involving metal bound water and $\mathrm{N}$ atom of quinoxalinone (along crystallographic axis " $c$ ") lead to the formation of a 3D hydrogen bonded network (Fig. 5d). If the discrete $\left[\mathrm{Fe}\left(\mathbf{L}_{2}\right)_{2}\left(\mathrm{H}_{2} \mathrm{O}\right)_{2}\right]$ complex, and twelve membered ring synthons are taken as nodes, the $3 \mathrm{D}$ hydrogen bonded network can be simplified to a $3 \mathrm{D}\left[3^{2} \cdot 6\right.$-c]-connected net having point (Schläfli) symbol of $\left\{4 \cdot 8^{2}\right\}_{2}\left\{4^{2} \cdot 6\right\}_{2}\left\{4^{2} \cdot 8^{10} \times\right.$ $\left.10^{3}\right\}$ (Fig. 5e).

\subsection{Hirshfeld surface analysis}

To further explore the supramolecular interactions in the crystal structure of the coordination compounds, we have constructed their Hirshfeld surface and 2D-fingerprint plots by using Crystal Explorer program..$^{55}$ The surface where the electron density $\rho_{\text {int }}(r)$ of the molecules is larger than the electron density $\rho_{\text {ext }}(r)$ of the adjacent molecules is called the Hirshfeld surface. ${ }^{56}$ Hirshfeld surfaces (HS) of the coordination compounds $\mathbf{C}_{\mathbf{1}}, \mathbf{C}_{\mathbf{2}}$ and $\mathbf{C}_{3}$ are shown in Fig. 6 , displaying the surface map over the normalized contact distance $\left(d_{\text {norm }}\right)$ in which the red and white colors indicating strong proximity and intermediate closeness of atoms to the HS from outside, respectively. We have used the following equation to calculate $d_{\text {norm }}$ from the values of $d_{\mathrm{e}}$ (distance between the Hirshfeld surface and external molecule), $d_{\mathrm{i}}$ (distance between the Hirshfeld surface and inside molecule) and van der Waals radii of the atoms $\left(r_{\mathrm{i}}^{\mathrm{vdw}}\right.$ or $\left.r_{\mathrm{e}}^{\mathrm{vdw}}\right)$. From the value of $d_{\text {norm }}$, we can easily determine the regions participating in the intermolecular interactions in the complexes.

$$
d_{\text {norm }}=\frac{d_{\mathrm{i}}-r_{\mathrm{i}}^{\mathrm{vdw}}}{r_{\mathrm{i}}^{\mathrm{vdw}}}+\frac{d_{\mathrm{e}}-r_{\mathrm{e}}^{\mathrm{vdw}}}{r_{\mathrm{e}}^{\mathrm{vdw}}}
$$

In other words, these two colors indicating strong and intermediate hydrogen bonding interactions present between HS and neighboring atoms outside, respectively. The blue color regions in the HS meaning the longer distances than the van der Waals radii. The HS of C1 was generated by using a standard (high) surface resolution with $3 \mathrm{D} d_{\text {norm }}$ surfaces mapped to a range -0.3180 to 1.5585 a.u. From the $d_{\text {norm }}$ mapping, it is

\section{a)}

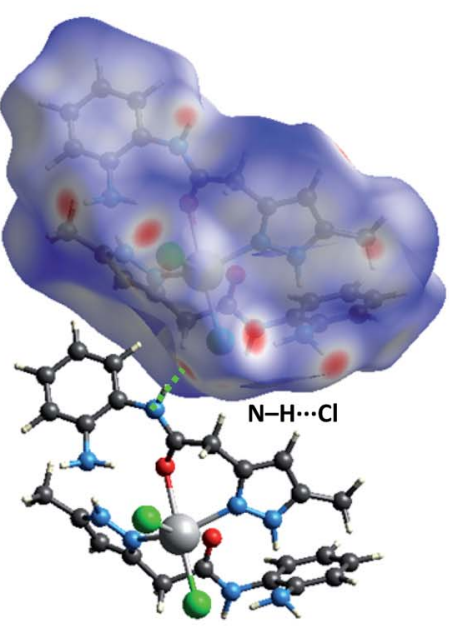

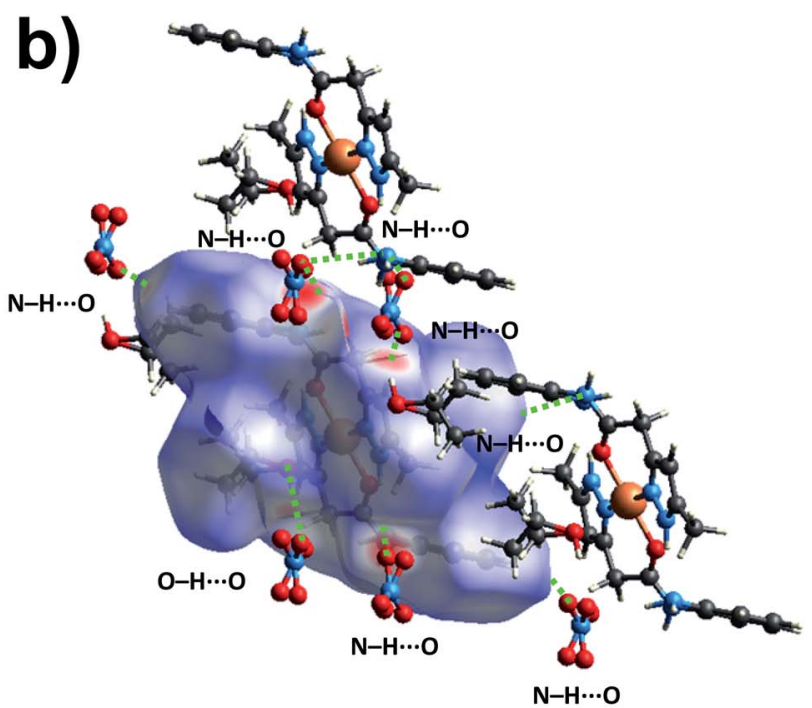

$\mathrm{N}-\mathrm{H} \cdots \mathbf{O}$

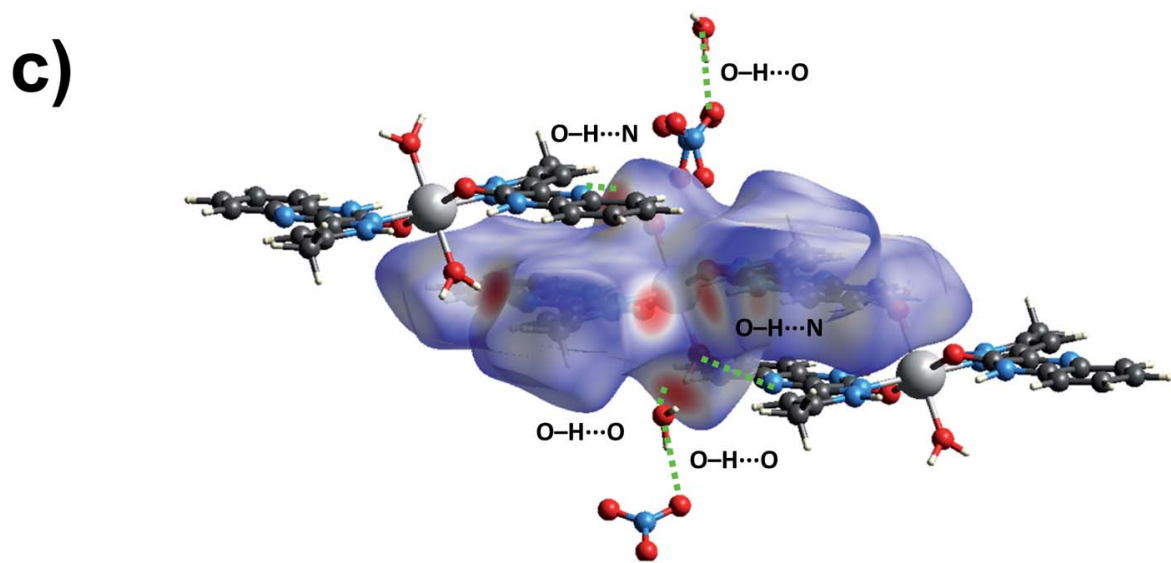

Fig. 6 The $d_{\text {norm }}$ Hirshfeld surfaces of $C_{1}(a), C_{2}$ (b), and $C_{3}$ (c) displaying hydrogen bonding interactions. 
revealed that strong $\mathrm{N}-\mathrm{H} \cdots \mathrm{Cl}$ hydrogen bonding interaction (between amide moiety of $\mathbf{L}_{\mathbf{1}}$ and chloride anion) was present in the crystal structure of $\mathbf{C}_{\mathbf{1}}$, as observed from the bright red spots on the HS. The $3 \mathrm{D} d_{\text {norm }}$ surfaced mapping of $\mathbf{C}_{2}$ was done within the range of -0.5718 to 1.7268 a.u which showed bright red spots at amine and amide $\mathrm{N}-\mathrm{H}$ (due to strong $\mathrm{N}-\mathrm{H} \cdots \mathrm{O}$ hydrogen bonding with nitrate counter anion), and metal bound water molecule $(\mathrm{O}-\mathrm{H} \cdots \mathrm{O}$ hydrogen bonding with nitrate). In the case of complex $\mathbf{C}_{3}$, the $3 \mathrm{D} d_{\text {norm }}$ surfaced mapping (range of -0.7131 to 1.2768 a.u.) showed red spots near to metal bound water molecule and quinoxalinone moiety (due to strong $\mathrm{O}-\mathrm{H} \cdots \mathrm{O}$ and $\mathrm{O}-\mathrm{H} \cdots \mathrm{N}$ hydrogen bonding). We have also plotted the shape index and curvedness of the coordination complexes by using Crystal Explorer program; the red concave surface surrounded by the receptors and blue convex surface surrounding receptors on the HS in the shape index of the coordination complexes further confirm the presence of such hydrogen bonding (Fig. S13 and S14, $\dagger$ ESI).

In order to quantify the contribution of various supramolecular interactions in the coordination complexes $\mathbf{C}_{\mathbf{1}}, \mathbf{C}_{\mathbf{2}}$ and $\mathbf{C}_{3}$, we have plotted their $2 \mathrm{D}$ fingerprints by using Crystal Explorer program (Fig. 7 and S15-S17, $\dagger$ ESI). The internal $d_{\mathrm{i}}$ and external $d_{\mathrm{e}}$ distances between the HS and atom contacts are given in $\AA$. We found that two strong hydrogen bonding $\mathrm{N}-\mathrm{H} \cdots \mathrm{O}$ and $\mathrm{N}-\mathrm{H} \cdots \mathrm{Cl}$ are presented in the crystal structure of $\mathbf{C}_{\mathbf{1}}$ which corroborated well with their $2 \mathrm{D}$ fingerprints; meaning the contributions of the interatomic contacts to the HF such as $\mathrm{Cl} \cdots \mathrm{H} / \mathrm{H} \cdots \mathrm{Cl}(16.1 \%)$ and $\mathrm{O} \cdots \mathrm{H} / \mathrm{H} \cdots \mathrm{O}(7.3 \%)$. Moreover, other weak interatomic contacts to the $\mathrm{HF}$ of $\mathrm{C} 1$ such as $\mathrm{N} \cdots \mathrm{H} / \mathrm{H} \cdots \mathrm{N}$ (4.5\%), $\mathrm{C} \cdots \mathrm{H} / \mathrm{H} \cdots \mathrm{C}(17.6 \%), \mathrm{H} \cdots \mathrm{H} / \mathrm{H} \cdots \mathrm{H}(49.6 \%)$ and $\mathrm{C} \cdots \mathrm{C} /$ $\mathrm{C} \cdots \mathrm{C}(2.9 \%)$ are also present in the $2 \mathrm{D}$ fingerprint. Similarly, the main contributions of the compounds $\mathbf{C}_{2}$ and $\mathbf{C}_{3}$ to the HS are assigned to the close contacts of $\mathrm{O} \cdots \mathrm{H} / \mathrm{H} \cdots \mathrm{O}\left(25 \%\right.$ for $\mathbf{C}_{2}$ and $25.5 \%$ for $\left.\mathbf{C}_{3}\right), \mathrm{N} \cdots \mathrm{H} / \mathrm{H} \cdots \mathrm{N}\left(2.3 \%\right.$ for $\mathbf{C}_{2}$ and $6.7 \%$ for $\left.\mathbf{C}_{3}\right), \mathrm{C} \cdots \mathrm{H} /$ $\mathrm{H} \cdots \mathrm{C}\left(13.9 \%\right.$ for $\mathbf{C}_{2}$ and $10 \%$ for $\left.\mathbf{C}_{3}\right), \mathrm{H} \cdots \mathrm{H} / \mathrm{H} \cdots \mathrm{H}\left(57.5 \%\right.$ for $\mathbf{C}_{2}$ and $40.5 \%$ for $\left.\mathrm{C}_{3}\right), \mathrm{C} \cdots \mathrm{C} / \mathrm{C} \cdots \mathrm{C}\left(1.3 \%\right.$ for $\mathrm{C}_{2}$ and $8.8 \%$ for $\left.\mathrm{C}_{3}\right)$ and $\mathrm{N} \cdots \mathrm{C} / \mathrm{N} \cdots \mathrm{C}\left(6.7 \%\right.$ for $\left.\mathrm{C}_{2}\right)$. The interatomic contacts such as $\mathrm{O} \cdots$ $\mathrm{H} / \mathrm{H} \cdots \mathrm{O}, \mathrm{N} \cdots \mathrm{H} / \mathrm{H} \cdots \mathrm{N}, \mathrm{C} \cdots \mathrm{H} / \mathrm{H} \cdots \mathrm{C}, \mathrm{H} \cdots \mathrm{H} / \mathrm{H} \cdots \mathrm{H}, \mathrm{C} \cdots \mathrm{C} / \mathrm{C} \cdots \mathrm{C}$ present in the 2D fingerprints of $\mathbf{C}_{2}$ and $\mathbf{C}_{3}$ corroborate well with the supramolecular interactions such as $\mathrm{N}-\mathrm{H} \cdots \mathrm{O}, \mathrm{C}-\mathrm{H} \cdots \mathrm{N}, \mathrm{C}-$ $\mathrm{H} \cdots \pi$, other van der Waals interactions and $\mathrm{C}-\mathrm{H} \cdots \pi / \pi \cdots \pi$ stacking, respectively present in their crystal structures (Fig. 7).

\subsection{Mössbauer spectroscopy}

A powdered sample of $\mathbf{C}_{3}$ was recorded at $298 \mathrm{~K}$. The spectrum shows a quadrupole doublet with isomer shift $\delta=0.346(3) \mathrm{mm}$ $\mathrm{s}^{-1}$ and quadrupole splitting $\Delta E_{\mathrm{Q}}=0.72(1) \mathrm{mm} \mathrm{s}^{-1}$ (Fig. 8). Such a doublet is characteristic of high-spin $\mathrm{Fe}(\mathrm{III})$ species. Measurements were also recorded at high velocity up to $v_{\max }=$ $10 \mathrm{~mm} \mathrm{~s}^{-1}$ but no oxides were detected. This result contrasts with the one offered by single crystal X-ray diffraction which revealed $\mathrm{Fe}(\mathrm{II})$ species only. A microscope analysis shows that the powder contains few orange single crystals, whereas the majority of the powder is black. A crystal cell parameters analysis of orange crystals revealed similar parameters as those given in Table 1 . This result is confirmed by powder X-ray
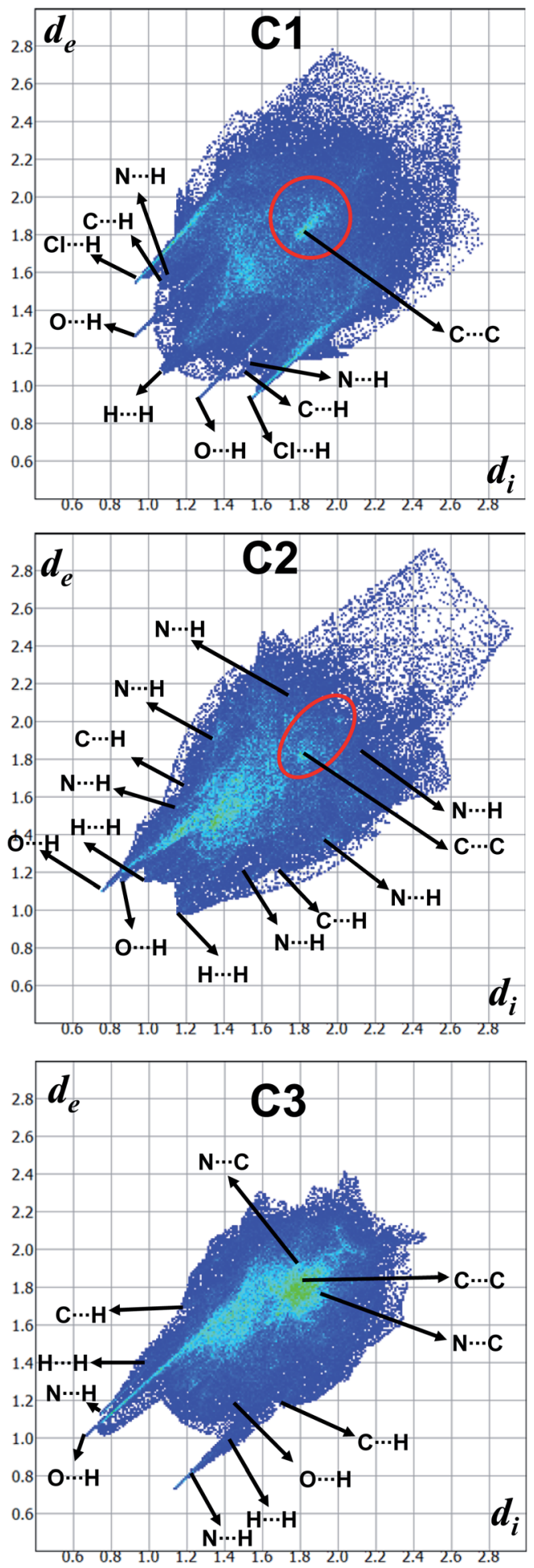

Fig. 7 2D Fingerprint plots derived from the Hirshfeld surfaces displaying various intermolecular interactions.

diffraction of the powdered sample which shows an amorphous pattern plus diffraction peaks. These diffraction peaks correspond to the simulated ones from the cif file of $\mathbf{C}_{3}$ (Fig. 9). Worth to note that the amount of $\mathbf{C}_{3}$ detected in the powder was evaluated below the detection limit of Mössbauer spectroscopy, i.e. ca. $2 \%$. 


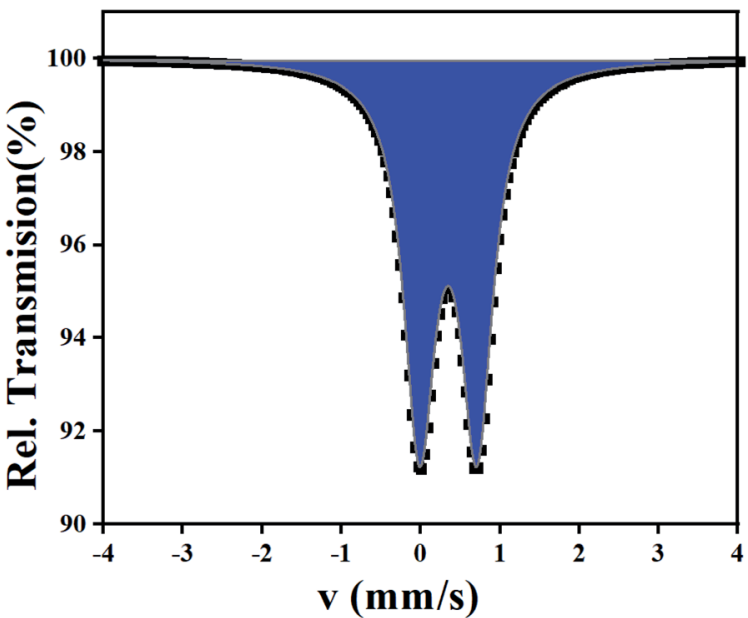

Fig. $8{ }^{57} \mathrm{Fe}$ Mössbauer spectrum of $\mathrm{C}_{3}$ recorded at $298 \mathrm{~K}$. The half width of the lines $\Gamma / 2=0.23(1) \mathrm{mm} \mathrm{s}^{-1}$.

\subsection{Antibacterial activity}

The antibacterial activities of the synthesized molecules ( 3 and $\mathbf{L}$ ) and metal complexes $\left(\mathbf{C}_{\mathbf{1}}, \mathbf{C}_{2}\right.$ and $\left.\mathbf{C}_{3}\right)$ were tested against $E$. coli and P. aeruginosa as Gram-negative and $S$. aureus and $S$. fasciens as Gram-positive microorganisms by the diffusion method disk. Table 3 reports the minimum inhibitory concentration (MIC) which is the lowest concentration for which no growth is detected for $24 \mathrm{~h}$ at $37^{\circ} \mathrm{C}$. The results were compared with a standard, chloramphenicol, an antibiotic, e.g. used for the treatment of eyelid infection, ${ }^{57}$ at various concentrations.
Table 3 Antibacterial activity of ligand and complexes (MIC, $\mu \mathrm{g} \mathrm{mL}^{-1}$ )

\begin{tabular}{lllll}
\hline & \multicolumn{2}{l}{$\mathrm{MIC}\left(\mu \mathrm{g} \mathrm{mL}^{-1}\right)$} \\
\cline { 2 - 5 } Compound & E. coli & P. aeruginosa & $\begin{array}{l}\text { S. } \\
\text { aureus }\end{array}$ & S. fasciens \\
\hline 3 & 10 & 10 & 20 & 5 \\
$\mathbf{L}_{\mathbf{1}}$ & 20 & 20 & 20 & 20 \\
$\mathbf{C}_{\mathbf{1}}$ & 5 & 5 & 5 & 10 \\
$\mathbf{C}_{\mathbf{2}}$ & 5 & 10 & 5 & 20 \\
$\mathbf{C}_{3}$ & 20 & 5 & 10 & 20 \\
Chloramphenicol & 6.25 & 6.25 & 12.5 & 6.25
\end{tabular}

Overall the three complexes showed higher antibacterial activities against the four strains tested, compared to $\mathbf{3}$ and $\mathbf{L}_{\mathbf{1}}$ ligand, except in the case of $S$. fasciens with a remarkable MIC $=$ $5 \mu \mathrm{g} \mathrm{mL}{ }^{-1}$ for $\mathbf{3}$ (Table 3). Such antibacterial activity of the $\mathbf{C}_{\mathbf{1}}-\mathbf{C}_{3}$ complexes compared to the ligand, could be due to the coordination of cadmium, copper and iron metal ions to the condensed ring system (as shown by single crystal X-ray diffraction), thus increasing the delocalization of $\pi$ electrons throughout the chelated ring and improving the lipophilicity of the complexes and thus the penetration of the complexes into the lipid membrane and further limiting the multiplicity of microorganisms, following Overtone's concept on cell permeability, ${ }^{58}$ and Tweedy's chelation theory. ${ }^{59}$

Remarkably, $\mathbf{C}_{\mathbf{1}}$ reveals an outstanding activity against both Gram-negative (E. coli and P. aeruginosa) and Gram-positive ( $S$. aureus) bacteria, compared to $\mathbf{C}_{2}, \mathbf{C}_{3}$ complexes, with a MIC value of $5 \mu \mathrm{g} \mathrm{mL}{ }^{-1}$. This value is even better compared to chloramphenicol, a well-known antibiotic. Similarly, $\mathbf{C}_{2}$ reveals

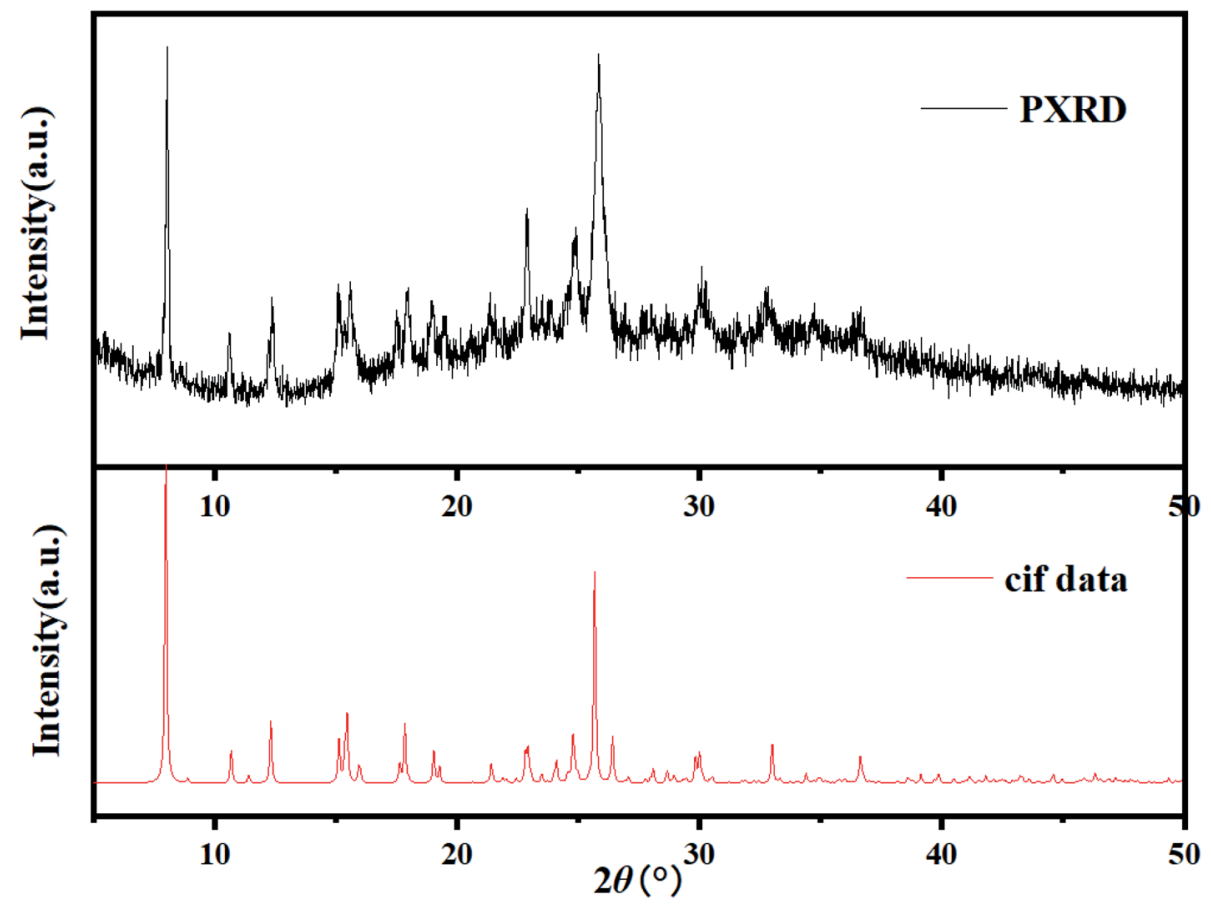

Fig. 9 XRPD pattern of the black powder issued from the synthesis of $C_{3}$ compared to the computed XPRD pattern obtained from the cif file of $\mathrm{C}_{3}$. 
Table 4 Antibacterial activity of $C_{1}, C_{2}, C_{3}$ and other model complexes

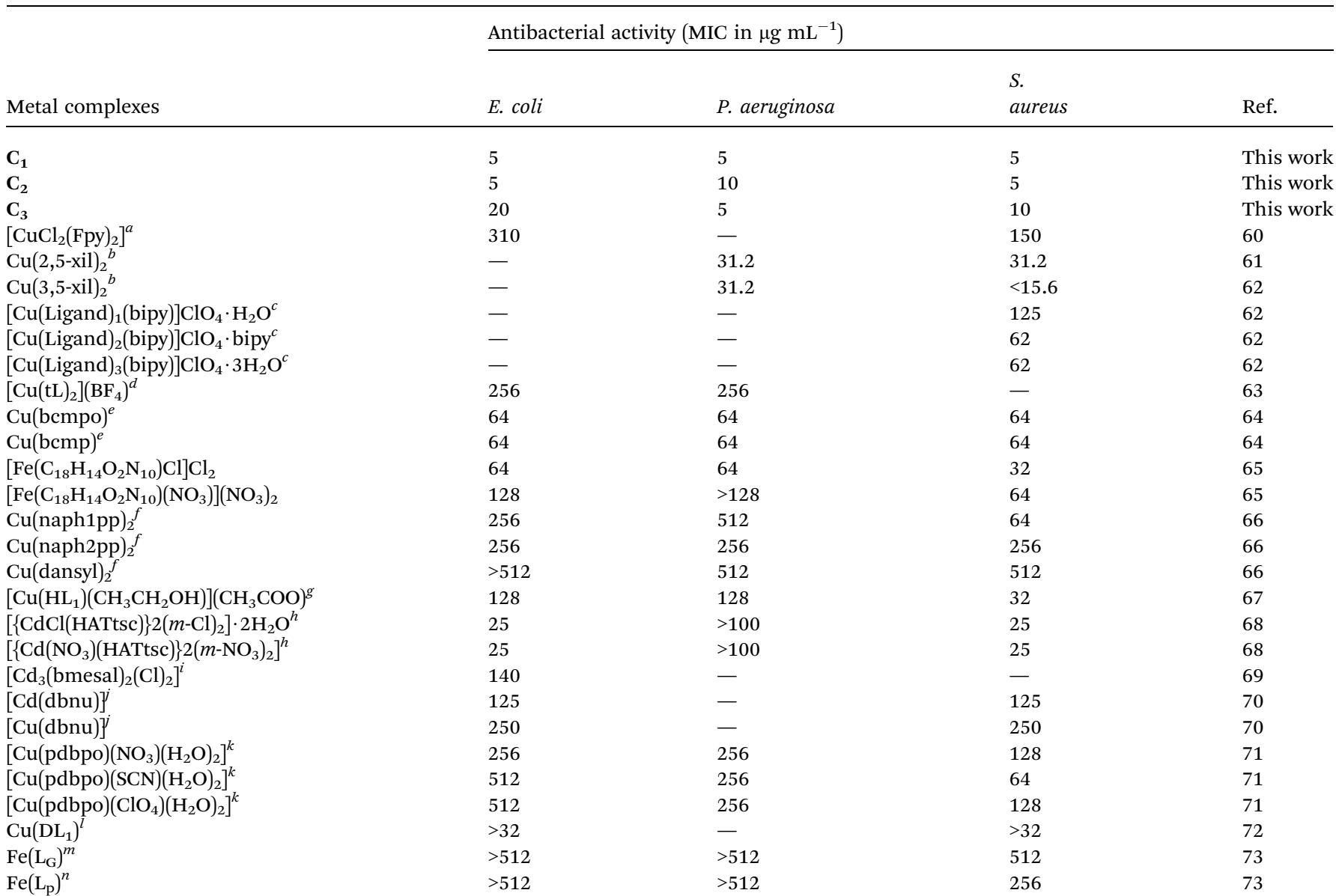

${ }^{a}$ Fpy $=2$-fluoropyridine. ${ }^{b}$ 2,5-xil $=2,5$-dimethylaniline, 3,5-xil $=3,5$-dimethylaniline ${ }^{c}$ bipy $=2,2^{\prime}$-bipyridine; ligand $=$ reaction between meso-1,2diphenyl-1,2-ethylenediamine with salicylaldehyde (1), 5-bromosalicylaldehyde (2) or 3-methoxysalicylaldehyde (3). ${ }^{d}$ tL $=$ reaction of 2 aminofluorene with 2-pyridinecarboxaldehyde. ${ }^{e}$ bcmpo $=3$-bis $\left(3^{\prime}\right.$-carboxyl-5'-methyl-1'-pyrazolyl)propan-2-ol; bcmp $=1,3$-bis $\left(3^{\prime}\right.$-carboxyl-5'methyl-1'-pyrazolyl), 2-methyl propane. ${ }^{f}$ naph1pp $=3$-hydroxy-2-methyl-1-naphthyl-4-pyridinonate; naph2pp $=1$ - $(N$-naphthylcarbamoylpropyl)3-hydroxy-2-methyl-4-pyridinonate; dansylpp $=2$-(N-dansylaminomethyl)-3-hydroxy-1,6-dimethyl-4-pyridinonate. ${ }^{g} \mathrm{HL}_{1}=N, N^{\prime}$-bis(salicylidene) diethylenetriamine. ${ }^{h}$ HATtsc $=2$-acetyl-2-thiazoline thiosemicarbazone. ${ }^{i}$ bmesal $=N, N^{\prime}$-bis(3-methoxysalicylidenimino)-1,3-diaminopropane. ${ }^{j} \mathrm{dbnu}=1,3$-diethyl-1,3-bis(4-nitrophenyl)urea. ${ }^{k}$ pdbpo $=1$-phenyl-2,3-dimethyl-4-( $N$-2-hydroxy-4-methoxy-benzaldehyde)-3-pyrazolin-5-one. ${ }^{l} \mathrm{DL}_{1}=N, N^{\prime}$-bis(1-(4-hydroxy-6-methyl-2-oxo-2H-pyran-3-yl)ethylidene)malonohydrazide. ${ }^{m} \mathrm{~L}_{\mathrm{G}}=2$-( $((2$-hydroxynaphthalen-1-yl)methylene)amino $)$ e andthane-1,1-diol. ${ }^{n} \mathrm{~L}_{\mathrm{p}}=2$-(((2-hydroxynaphthalen-1-yl)methylene)amino)-2-phenylethane-1,1-diol.

an identical MIC for $E$. coli and $S$. aureus, whereas $\mathbf{C}_{3}$ show excellent activity against $P$. aeruginosa $\left(\mathrm{MIC}=5 \mu \mathrm{g} \mathrm{mL}{ }^{-1}\right)$ and very good activity towards $S$. aureus.

Most excitingly, superior values are found compared to earlier literature reports on $\mathrm{Cd}(\mathrm{II}), \mathrm{Cu}$ (II) and $\mathrm{Fe}(\mathrm{II})$ complexes (Table 4).

\section{Conclusions}

In conclusion, three new $\mathrm{Cd}(\mathrm{II}), \mathrm{Cu}(\mathrm{II})$ and $\mathrm{Fe}(\mathrm{II})$ complexes formulated as $\left[\mathrm{Cd}\left(\mathbf{L}_{\mathbf{1}}\right)_{2} \mathrm{Cl}_{2}\right]\left(\mathbf{C}_{\mathbf{1}}\right),\left[\mathrm{Cu}\left(\mathbf{L}_{\mathbf{1}}\right)_{2}\left(\mathrm{C}_{2} \mathrm{H}_{5} \mathrm{OH}\right)_{2}\right]\left(\mathrm{NO}_{3}\right)_{2}\left(\mathbf{C}_{\mathbf{2}}\right)$ and $\left[\mathrm{Fe}\left(\mathbf{L}_{2}\right)_{2}\left(\mathrm{H}_{2} \mathrm{O}\right)_{2}\right]\left(\mathrm{NO}_{3}\right)_{2} \cdot 2 \mathrm{H}_{2} \mathrm{O}\left(\mathbf{C}_{3}\right)$ have been synthesized and their crystal structures have been studied. Crystal structure and Hirshfeld Surface analysis have shown that the crystal lattices of all the complexes are influenced for the presence of several intermolecular interactions, including hydrogen bonds. The $\mathrm{N}-\mathrm{H} \cdots \mathrm{O}$ and $\mathrm{N}-\mathrm{H} \cdots \mathrm{Cl}$ hydrogen bonding interactions benefits to $\mathbf{C}_{\mathbf{1}}$, which is the first coordination complex with $\mathbf{L}_{\mathbf{1}}$, to assemble to form a $1 \mathrm{D}$ chain as a primary supramolecular architecture. On the other hand, in complex $\mathrm{C}_{2}, \mathrm{~N}-\mathrm{H} \cdots \mathrm{O}$ and $\mathrm{O}-\mathrm{H} \cdots \mathrm{O}$ hydrogen bonding play a role to self-assemble the crystallographically independent molecules of complexes and ethanol molecules to form a 2D corrugated hydrogen bonded sheet. The layers are joined by inversion-related $\mathrm{C}-\mathrm{H} \cdots \mathrm{O}$ hydrogen bonds. On another hand in complex $\mathbf{C}_{3}$, the iron ion is coordinated by two chelating organic ligands and two water molecules with a slightly distorted octahedral geometry. $\mathrm{O}-\mathrm{H} \cdots$ $\mathrm{O}, \mathrm{N}-\mathrm{H} \cdots \mathrm{O}$ and $\mathrm{O}-\mathrm{H} \cdots \mathrm{N}$ hydrogen bonds and $\pi$-stacking interactions form layers of cations, anions and solvent water molecules. These are further linked into the full threedimensional structure by additional hydrogen bonds. Furthermore, the results of antibacterial activity testing reveal that $\mathbf{C}_{\mathbf{1}}$, $\mathbf{C}_{2}$ and $\mathbf{C}_{3}$ complexes showed notable activity against all four strains of bacteria studied. Thus, the best result was shown by 
$\mathbf{C}_{\mathbf{1}}$, against $E$. coli, $P$. aeruginosa and $S$. aureus bacterial strains, with a remarkable MIC of $5 \mu \mathrm{g} \mathrm{mL} \mathrm{m}^{-1}$.

\section{Conflicts of interest}

The authors declare no competing financial interest.

\section{Acknowledgements}

We acknowledge financial support from Wallonie Bruxelles International (WBI COP22 Morocco), CNRST (ESRFC-CNRSTP10) and FNRS (PDR T.0095.21).

\section{References}

1 U. Ndagi, A. A. Falaki, M. Abdullahi, M. M. Lawal and M. E. Soliman, Antibiotic resistance: bioinformatics-based understanding as a functional strategy for drug design, RSC Adv., 2020, 10, 18451-18468.

2 European Centre for Disease Prevention and Control, Antibiotic Resistance: An Increasing Threat to Human Health, 2018,https://antibiotic.ecdc.europa.eu/en/ publications-data/antibiotic-resistanceincreasing-threat-

human-health, accessed on 18 Jan. 2022.

3 Atlanta, GA: US Centers for Disease Control and Prevention, Antibiotic Resistance Threats in the United States, 2019,https:/www.cdc.gov/drugresistance/pdf/threats-report/ 2019-ar-threatsreport-508.pdf, accessed on 18 Jan. 2022.

4 Geneva: World Health Organization, Antimicrobial resistance,https:/www.who.int/news-room/fact-sheets/ detail/antimicrobial-resistance, accessed on 18 Jan. 2022.

5 P. K. Bhaumik, K. Ghosh and S. Chattopadhyay, Synthetic strategies, crystal structures and biological activities of metal complexes with the members of azole family: A review, Polyhedron, 2021, 200, 115093.

6 K. Karrouchi, S. Radi, Y. Ramli, J. Taoufik, Y. N. Mabkhot, F. A. Al-Aizari and M. Ansar, Synthesis and Pharmacological Activities of Pyrazole Derivatives: A Review, Molecules, 2018, 23, 134.

7 F. E. Bennani, L. Doudach, Y. Cherrah, Y. Ramli, K. Karrouchi, M. Ansar and M. E. Faouzi, Overview of recent developments of pyrazole derivatives as an anticancer agent in different cell line, Bioorg. Chem., 2020, 97, 103470.

8 K. Karrouchi, S. A. Brandán, M. Hassan, K. Bougrin, S. Radi, M. Ferbinteanu, Y. Garcia and M. h. Ansar, Synthesis, X-ray, spectroscopy, molecular docking and DFT calculations of (E)-N'-(2,4-dichlorobenzylidene)-5-phenyl-1H-pyrazole-3carbohydrazide, J. Mol. Struct., 2021, 1228, 129714.

9 W. A. A. Fadaly, Y. Elshaier, E. H. M. Hassanein and K. R. Abdellatif, New 1,2,4-triazole/pyrazole hybrids linked to oxime moiety as nitric oxide donor celecoxib analogs: Synthesis, cyclooxygenase inhibition anti-inflammatory, ulcerogenicity, anti-proliferative activities, apoptosis, molecular modeling and nitric oxide release studies, Bioorg. Chem., 2020, 98, 103752.
10 K. Karrouchi, S. A. Brandán, Y. Sert, H. El-marzouqi, S. Radi, M. Ferbinteanu, M. E. A. Faouzi, Y. Garcia and M. h. Ansar, Synthesis, X-ray structure, vibrational spectroscopy, DFT, biological evaluation and molecular docking studies of (E)N'-(4-(dimethylamino)benzylidene)-5-methyl-1H-pyrazole-3carbohydrazide, J. Mol. Struct., 2020, 1219, 128541.

11 K. Karrouchi, S. A. Brandán, Y. Sert, M. E. Karbane, S. Radi, M. Ferbinteanu, Y. Garcia and M. h. Ansar, Synthesis, structural, molecular docking and spectroscopic studies of (E)-N'-(4-methoxybenzylidene)-5-methyl-1H-pyrazole-3carbohydrazide, J. Mol. Struct., 2021, 1225, 129072.

12 O. I. el-Sabbagh, M. M. Baraka, S. M. Ibrahim, C. Pannecouque, G. Andrei, R. Snoeck, J. Balzarini and A. A. Rashad, Synthesis and antiviral activity of new pyrazole and thiazole derivatives, Eur. J. Med. Chem., 2009, 44, 3746-3753.

13 K. Karrouchi, L. Chemlal, J. Taoufik, Y. Cherrah, S. Radi, M. El Abbes Faouzi and M. Ansar, Synthesis, antioxidant and analgesic activities of Schiff bases of 4-amino-1,2,4triazole derivatives containing a pyrazole moiety, Ann. Pharm. Fr., 2016, 74, 431-438.

14 E. Guillén, A. González, P. K. Basu, A. Ghosh, M. Font-Bardia, T. Calvet, C. Calvis, R. Messeguer and C. López, The influence of ancillary ligands on the antitumoral activity of new cyclometallated Pt(II) complexes derived from an ferrocene-pyrazole hybrid, J. Organomet. Chem., 2017, 828, 122-132.

15 K. Karrouchi, E. B. Yousfi, N. K. Sebbar, Y. Ramli, J. Taoufik, Y. Ouzidan, M. Ansar, Y. N. Mabkhot, H. A. Ghabbour and S. Radi, New Pyrazole-Hydrazone Derivatives: X-ray Analysis, Molecular Structure Investigation via Density Functional Theory (DFT) and Their High In-Situ Catecholase Activity, Int. J. Mol. Sci., 2017, 18, 2215.

16 S. Tighadouini, R. Benabbes, M. Tillard, D. Eddike, K. Haboubi, K. Karrouchi and S. Radi, Synthesis, crystal structure, DFT studies and biological activity of (Z)-3-(3bromophenyl)-1-(1,5-dimethyl-1H-pyrazol-3-yl)-3-

hydroxyprop-2-en-1-one, Chem. Cent. J., 2018, 12, 122.

17 N. Kwon, D. Kim, K. M. K. Swamy and J. Yoon, Metalcoordinated fluorescent and luminescent probes for reactive oxygen species (ROS) and reactive nitrogen species (RNS), Coord. Chem. Rev., 2021, 427, 213581.

18 P. S. Donnelly, The role of coordination chemistry in the development of copper and rhenium radiopharmaceuticals, Dalton Trans., 2011, 40, 999-1010.

19 S. Kashyap, R. Singh and U. P Singh, Inorganic and organic anion sensing by azole family members, Coord. Chem. Rev., 2020, 417, 213369.

20 S. N. Sovari and F. Zobi, Recent studies on the antimicrobial activity of transition metal complexes of groups 6-12, Chem, 2020, 2, 418-452.

21 M. A. Malik, O. A. Dar, P. Gull, M. Y. Wani and A. A. Hashmi, Heterocyclic Schiff base transition metal complexes in antimicrobial and anticancer chemotherapy, MedChemComm, 2018, 9, 409-436.

22 F. Li, J. G. Collins and F. R. Keene, Ruthenium complexes as antimicrobial agents, Chem. Soc. Rev., 2015, 44, 2529-2542. 
23 M. Claudel, J. V. Schwarte and K. M. Fromm, New antimicrobial strategies based on metal complexes, Chem, 2020, 2, 849-899.

24 D. H. Nakahata, R. E. de Paiva, W. R. Lustri and P. P. Corbi, Sulfonamide-containing copper(ii) complexes: new insights on biophysical interactions and antibacterial activities, New J. Chem., 2020, 44, 17236-17244.

25 A. Frei, Metal complexes, an untapped source of antibiotic potential?, Antibiotics, 2020, 9, 90.

26 Y. Lin, H. Betts, S. Keller, K. Cariou and G. Gasser, Recent developments of metal-based compounds against fungal pathogens, Chem. Soc. Rev., 2021, 50, 10346-10402.

27 I. Casanova, M. L. Durán, J. Viqueira, A. Sousa-Pedrares, F. Zani, J. A. Real and J. A. García-Vázquez, Metal complexes of a novel heterocyclic benzimidazole ligand formed by rearrangement-cyclization of the corresponding Schiff base. Electrosynthesis, structural characterization and antimicrobial activity, Dalton Trans., 2018, 47, 43254340 .

28 S. Omidi and A. Kakanejadifard, A review on biological activities of Schiff base, hydrazone, and oxime derivatives of curcumin, RSC Adv., 2020, 10, 30186-30202.

29 M. A. Malik, O. A. Dar, P. Gull, M. Y. Wani and A. A. Hashmi, Heterocyclic Schiff base transition metal complexes in antimicrobial and anticancer chemotherapy, MedChemComm, 2018, 9, 409-436.

30 R. F. Guo, H. T. Yan, R. X. Liu, H. C. Li, Y. C. Liu, Z. F. Chen and H. Liang, Structural characterization and pharmacological assessment in vitro/in vivo of a new copper(ii)-based derivative of enrofloxacin, Metallomics, 2020, 12, 2145-2160.

31 V. Jakobsen, L. Viganor, A. Blanco-Fernández, O. Howe, M. Devereux, C. J. McKenzie and V. McKee, Tetrameric and polymeric silver complexes of the omeprazole scaffold; synthesis, structure, in vitro and in vivo antimicrobial activities and DNA interaction, J. Inorg. Biochem., 2018, 186, 317-328.

32 A. Evans and K. A. Kavanagh, Evaluation of metal-based antimicrobial compounds for the treatment of bacterial pathogens, J. Med. Microbiol., 2021, 70, 001363.

33 Y. Huang, X. Hang, X. Jiang, L. Zeng, J. Jia, Y. Xie and H. Bi, In vitro and in vivo activities of zinc linolenate, a selective antibacterial agent against Helicobacter pylori, Antimicrob. Agents Chemother., 2019, 63, e00004-19.

34 P. Güntzel, C. Nagel, J. Weigelt, J. W. Betts, C. A. Pattrick, H. M. Southam and U. Schatzschneider, Biological activity of manganese(i) tricarbonyl complexes on multidrugresistant Gram-negative bacteria: From functional studies to in vivo activity in Galleria mellonella, Metallomics, 2019, 11, 2033-2042.

35 D. F. da Silva, J. C. Amaral, R. M. Carlos, A. G. Ferreira, M. R. Forim, J. B. Fernandes, M. F. G. Fernandes da Silva, H. D. Coletta Filho and A. A. de Souza, Octahedral ruthenium and magnesium naringenin 5-alkoxide complexes: NMR analysis of diastereoisomers and in-vivo antibacterial activity against Xylella fastidiosa, Talanta, 2021, 225, 122040.
36 D. Li, S. Gao, K. Ye, Q. Wang, C. Xie, W. Wu and Q. Pang, Membrane-active $\mathrm{La}(\mathrm{III})$ and $\mathrm{Ce}(\mathrm{III})$ complexes as potent antibacterial agents: synthesis, characterization, in vitro, in silico, and in vivo studies, J. Mol. Struct., 2022, 1249, 131595.

37 A. Frei, J. Zuegg, A. G. Elliott, M. Baker, S. Braese, C. Brown, F. Chen, C. G. Dowson, G. Dujardin, N. Jung, A. P. King, A. M. Mansour, M. Massi, J. Moat, H. A. Mohamed, A. K. Renfrew, P. J. Rutledge, P. J. Sadler, M. H. Todd, C. E. Willans, J. J. Wilson, M. A. Cooper and M. A. T. Blaskowich, Metal complexes as a promising source for new antibiotics, Chem. Sci., 2020, 11, 2627-2639.

38 G. Al Ati, K. Chkirate, J. T. Mague, N. Abad, R. Achour and E. M. Essasi, Crystal structure, Hirshfeld surface analysis and DFT study of N-(2-amino-5-methyl-phen-yl)-2-(5methyl-1H-pyrazol-3-yl)acetamide, Acta Crystallogr., Sect. E: Crystallogr. Commun., 2021, 77, 638-642.

39 K. Chkirate, S. Kansiz, K. Karrouchi, J. T. Mague, N. Dege and E. M. Essassi, Crystal structure and Hirshfeld surface analysis of $\mathrm{N}-\{2-[(\mathrm{E})-(4-\mathrm{methyl}-\mathrm{benzyl}$-idene)amino]-phenyl\}-2-(5-methyl-1-H-pyrazol-3-yl)acetamide hemihydrate, Acta Crystallogr., Sect. E: Crystallogr. Commun., 2019, 75, 154-158.

40 G. Al Ati, K. Chkirate, A. Mashrai, J. T. Mague, Y. Ramli, R. Achour and E. M. Essassi, Crystal structure, Hirshfeld surface analysis and DFT study of 1-ethyl-3-phenyl-1,2-dihydro-quinoxalin-2-one, Acta Crystallogr., Sect. E: Crystallogr. Commun., 2021, 77, 18-22.

41 K. Chkirate, R. Regragui, E. Essassi and M. Pierrot, Crystal structure of diaquabis [N-2-aminophenyl-5-methylpyrazol-yl acetamido] zinc(II) diperchlorate, $\mathrm{C}_{24} \mathrm{H}_{34} \mathrm{~N}_{8} \mathrm{O}_{4} \mathrm{Zn}\left(\mathrm{ClO}_{4}\right)_{2}, Z$. Kristallogr. N. Cryst. Struct., 2001, 216, 635-636.

42 K. Chkirate, S. Fettach, K. Karrouchi, N. K. Sebbar, E. M. Essassi, J. T. Mague, S. Radi, M. El Abbes Faouzi, N. N. Adarsh and Y. Garcia, Novel $\mathrm{Co}(\mathrm{II})$ and $\mathrm{Cu}(\mathrm{II})$ coordination complexes constructed from pyrazoleacetamide: Effect of hydrogen bonding on the self assembly process and antioxidant activity, J. Inorg. Biochem., 2019, 191, 21-28.

43 K. Chkirate, K. Karrouchi, N. Dege, N. Kheira Sebbar, A. Ejjoummany, S. Radi, N. N. Adarsh, A. Talbaoui, M. Ferbinteanu, E. M. Essassi and Y. Garcia, Co(ii) and $\mathrm{Zn}$ (ii) pyrazolyl-benzimidazole complexes with remarkable antibacterial activity, New J. Chem., 2020, 44, 2210-2221.

44 K. Chkirate, S. Fettach, M. El Hafi, K. Karrouchi, B. Elotmani, J. T. Mague, S. Radi, M. E. A. Faouzi, N. N. Adarsh, E. M. Essassi and Y. Garcia, Solvent induced supramolecular polymorphism in $\mathrm{Cu}(\mathrm{II})$ coordination complex built from 1,2,4-triazolo[1,5-a]pyrimidine: Crystal structures and anti-oxidant activity, J. Inorg. Biochem., 2020, 208, 111092.

45 G. M. Sheldrick, SHELXT - integrated space-group and crystal-structure determination, Acta Crystallogr., Sect. A: Found. Adv., 2015, 71, 3-8.

46 C. F. Macrae, P. R. Edgington, P. McCabe, E. Pidcock, G. P. Shields, R. Taylor, M. Towler and J. van de Streek, Mercury: visualization and analysis of crystal structures, $J$. Appl. Crystallogr., 2006, 39, 453-457. 
47 M. El Abbassi, E. Essassi and J. Fifani, Nouvelle synthese des benzodiazepines-1,5 à partir de la $\gamma$-pyrone, Tetrahedron Lett., 1987, 28, 1389-1392.

48 E. Essassi, M. Elabbassi and J. Fifani, Synthèse des Benzimidazolyl-2 Méthyl-5' Pyrazolyl-3' Méthanes a Partir des Acétylméthylène-4 Benzodiazepine-1,5 Ones-2, Bull. Soc. Chim. Belg., 1987, 96, 225-228.

49 E. S. Raper, A. Miller, T. Glowial and M. Kubiak, The crystal structure of bis[dichloro(2,2'-dithiazolyl-disulphide)iron(II)]: a novel iron(III) promoted in situ oxidation of thiazoline-2thione, Transition Met. Chem., 1989, 14, 319-320.

50 C. Brewer, G. Brewer, R. J. Butcher, E. E. Carpenter, L. Cuenca, B. C. Noll, W. R. Scheidt, C. Viragh, P. Y. Zavalij and D. Zielaski, Synthesis and characterization of manganese(II) and iron(III) $\mathrm{d}^{5}$ tripodal imidazole complexes. Effect of oxidation state, protonation state and ligand conformation on coordination number and spin state, Dalton Trans., 2006, 8, 1009-1019.

51 C. P. Raptopoulou, Y. Sanakis and A. K. Boudalis, Aerobic FeIII-FeII Reduction in the Presence of 2,4,6-Tri(2-pyridyl)1,3,5-triazine and Benzilic Acid: Synthesis and Characterization of a Heptacoordinate FeII-Nitrato Complex, Eur. J. Inorg. Chem., 2008, 36, 5632-5641.

52 H. Nasri, M. K. Ellison, B. Shaevitz, G. P. Gupta and W. R. Scheidt, Electronic, Magnetic, and Structural Characterization of the Five-Coordinate, High-Spin Iron(II) Nitrato Complex [Fe(TpivPP) $\left.\left(\mathrm{NO}_{3}\right)\right]$, Inorg. Chem., 2006, 45, 5284-5290.

53 C. P. Raptopoulou, V. Tangoulis and E. Devlin, $\left[\left\{\mathrm{Fe}(\mathrm{OMe})_{2}\left[\mathrm{O}_{2} \mathrm{CC}(\mathrm{OH}) \mathrm{Ph}_{2}\right]\right\}_{12}\right]$ : Synthesis and Characterization of a New Member in the Family of Molecular Ferric Wheels with the Carboxylatobis (alkoxo) Bridging Unit, Angew. Chem., Int. Ed., 2002, 41, 2386-2389.

54 M. Tiliakos, P. Cordopatis, A. Terzis, C. P. Raptopoulou, S. P. Perlepes and E. Manessi-Zoupa, Reactions of 3d-metal nitrates with $\mathrm{N}, \mathrm{N}^{\prime}$-bis(2-pyridyl)urea $\left(\mathrm{LH}_{2}\right)$ : preparation, Xray crystal structures and spectroscopic studies of the products trans-[M(II) $\left.\left(\mathrm{ONO}_{2}\right)_{2}\left(\mathrm{LH}_{2}\right)_{2}\right](\mathrm{M}=\mathrm{Mn}, \mathrm{Fe}, \mathrm{Co}, \mathrm{Ni}$, $\mathrm{Cu}, \mathrm{Zn})$ and mer-[Co(III) $\left.(\mathrm{LH})_{2}\right]\left(\mathrm{NO}_{3}\right) \cdot \mathrm{MeOH}$, Polyhedron, 2001, 20, 2203-2214.

55 S. Wolff, D. Grimwood, J. McKinnon, M. Turner, D. Jayatilaka and M. Spackman, Crystal explorer, University of Western Australia Crawley, Australia, 2012.

56 F. L. Hirshfeld, Bonded-atom fragments for describing molecular charge densities, Theor. Chim. Acta, 1977, 44, 129-138.

57 D. Lorenzo, Chloramphenicol Resurrected: A Journey from Antibiotic Resistance in Eye Infections to Biofilm and Ocular Microbiota, Microorganisms, 2019, 7, 278.

58 Y. Anjaneyulu and R. P. Rao, Preparation, Characterization and Antimicrobial Activity Studies on Some Ternary Complexes of $\mathrm{Cu}(\mathrm{II})$ with Acetylacetone and Various Salicylic Acids, Synth. React. Inorg. Met.-Org. Chem., 1986, 16, 257-272.

59 N. Dharmaraj, P. Viswanathamurthi and K. Natarajan, Ruthenium(II) complexes containing bidentate Schiff bases and their antifungal activity, Transition Met. Chem., 2001, 26, 105-109.

60 R. E. Demirdogen, D. Kilic, F. M. Emen, Ş. Aşkar, A. I. Karaçolak, T. Yesilkaynak and A. Ihsan, Novel antibacterial cellulose acetate fibers modified with 2fluoropyridine complexes, J. Mol. Struct., 2020, 1204, 127537.

61 E. B. Poormohammadi, M. Behzad, Z. Abbasi and S. D. A. Astaneh, Copper complexes of pyrazolone-based Schiff base ligands: Synthesis, crystal structures and antibacterial properties, J. Mol. Struct., 2020, 1205, 127603.

62 S. Alimirzaei, M. Behzad, S. Abolmaali and Z. Abbasi, Mixedligand copper complexes with unsymmetrical tridentate Schiff base ligands and 2,2'-bipyridine: Synthesis, X-ray crystallography and antibacterial properties, J. Mol. Struct., 2020, 1200, 127146.

63 O. L. Cifuentes-Vaca, J. Andrades-Lagos, J. CampaniniSalinas, A. Laguna, D. Vásquez-Velásquez and M. Concepción Gimeno, Silver(I) and copper(I) complexes with a Schiff base derived from 2-aminofluorene with promising antibacterial activity, Inorg. Chim. Acta, 2019, 489, 275-279.

64 T. Harit, H. Abouloifa, M. Tillard, D. Eddike, A. Asehraou and F. Malek, New copper complexes with bipyrazolic ligands: Synthesis, characterization and evaluation of the antibacterial and catalytic properties, J. Mol. Struct., 2018, 1163, 300-307.

65 M. Kamboj, D. P. Singh, A. K. Singh and D. Chaturvedi, Molecular modeling, in-silico docking and antibacterial studies of novel template wangled macrocyclic complexes involving isatin moiety, J. Mol. Struct., 2020, 1207, 127602.

66 Z. Mortezaei, M. Zendehdel and M. A. Bodaghifard, $\mathrm{Cu}$ complex grafted on the porous materials: synthesis, characterization and comparison of their antibacterial activity with nano-Cu/NaY zeolite, J. Iran. Chem. Soc., 2019, 17, 283-295.

67 C. Liu, M.-X. Chen and M. Li, Synthesis, crystal structures, catalytic application and antibacterial activities of $\mathrm{Cu}$ (II) and $\mathrm{Zn}$ (II) complexes bearing salicylaldehyde-imine ligands, Inorg. Chim. Acta, 2020, 508, 119639.

68 E. Vinuelas-Zahinos, F. Luna-Giles, P. Torres-Garcia and M. C. Fernandez-Calderon, Co(III), Ni(II), Zn(II) and Cd(II) complexes with 2-acetyl-2-thiazoline thiosemicarbazone: Synthesis, characterization, X-ray structures and antibacterial activity, Eur. J. Med. Chem., 2011, 46, 150-159.

69 D. Majumdar, S. Das, J. K Biswas and M. Mondal. Synthesis, structure, fluorescent property, and antibacterial activity of new Cd(II) metal complex based on multidentate Schiff base ligand N,N'-Bis(3-methoxysalicylidenimino)-1,3diaminopropane, J. Mol. Struct., 2017, 1134, 617-624.

70 H. Pasdar, B. Hedayati Saghavaz, N. Foroughifar and M. Davallo, Synthesis, Characterization and Antibacterial Activity of Novel 1,3-Diethyl-1,3-bis(4-nitrophenyl)urea and Its Metal(II) Complexes, Molecules, 2017, 22, 2125.

71 T. Rosu, E. Pahontu, C. Maxim, R. Georgescu, N. Stanica and A. Gulea, Some new $\mathrm{Cu}(\mathrm{II})$ complexes containing an $\mathrm{ON}$ donor Schiff base: Synthesis, characterization and antibacterial activity, Polyhedron, 2011, 30, 154-162. 
72 R. P. Saini, V. Kumar, A. K. Gupta and G. K. Gupta, Synthesis, characterization, and antibacterial activity of a novel heterocyclic Schiff's base and its metal complexes of first transition series, Med. Chem. Res., 2013, 23, 690-698.
73 F. Sevgi, U. Bagkesici, A. N. Kursunlu and E. Guler, Fe(III), $\mathrm{Co}(\mathrm{II}), \mathrm{Ni}(\mathrm{II}), \mathrm{Cu}(\mathrm{II})$ and $\mathrm{Zn}$ (II) complexes of schiff bases based-on glycine and phenylalanine: Synthesis, magnetic/ thermal properties and antimicrobial activity, J. Mol. Struct., 2018, 1154, 256-260. 